https://doi.org/10.11646/zootaxa.4415.3.1

http://zoobank.org/urn:lsid:zoobank.org:pub:C7CBCC78-312C-4AAF-B3D2-DA4AD73E139D

\title{
A new species of Uropeltis Cuvier, 1829 (Serpentes: Uropeltidae) from the Anaikatty Hills of the Western Ghats of India
}

\author{
V.J. JINS ${ }^{1}$, FILIPA L. SAMPAIO ${ }^{2} \&$ DAVID J. GOWER ${ }^{2,3}$ \\ ${ }^{1}$ Sálim Ali Centre for Ornithology and Natural History, Anaikatty, Coimbatore 641 108, India \\ ${ }^{2}$ Department of Life Sciences, The Natural History Museum, London SW7 5BD, UK \\ ${ }^{3}$ Corresponding author.E-mail:d.gower@nhm.ac.uk
}

\begin{abstract}
A new species of Uropeltis is described from a series of six type specimens from the Anaikatty Hills of the Western Ghats of Tamil Nadu, peninsular India. Uropeltis bhupathyi sp. nov. is distinguished from congeners by having more than 200 ventral scales, 17 dorsal scale rows at midbody and by the size and shape of the rostral and frontal shields. Although tens of specimens have been seen in the vicinity of the type locality (and previously reported as $U$. ellioti), the new species is known only from this locality and faces threats from road traffic, habitat loss and change, and possibly a condition that deforms heads and head shields which is at least superficially similar to snake fungal disease reported from wild snakes in North America and Europe.
\end{abstract}

Key words: shieldtail, snake, snake fungal disease, systematics, taxonomy, Uropeltis ellioti, Western Ghats

\section{Introduction}

The most recent comprehensive list of currently recognised shieldtail snake (Uropeltidae) species of South Asia includes 23 nominal species of the endemic Indian genus Uropeltis Cuvier, 1829 (Pyron et al. 2016). Of these, according to Smith (1943) and Constable (1949) only three species have 17 dorsal scale rows at midbody and ventral scale counts that exceed 200: U. ocellata (Beddome, 1863), U. macrorhyncha (Beddome, 1877) and U. nitida (Beddome, 1878). We examined specimens of a population of Uropeltis from the Anaikatty hills in the Western Ghats that had been identified previously (Kannan \& Bhupathy 1997; Mukherjee 2007) as U. ellioti (Gray, 1858), a species whose holotype has 167 ventrals (pers. obs.). All examined specimens of the Anaikatty hills population have 17 dorsal scale rows at midbody and 202-220 ventrals. Closer examination of other features and comparisons with congeners lead us to here describe this form as a new species.

\section{Material and methods}

In addition to specimens of the new species deposited in the National Centre for Biological Sciences, Bangalore, India (NCBS), the Bombay Natural History Society, Mumbai, India (BNHS), and the Western Ghats Regional Centre of the Zoological Survey of India, Kozhikode (ZSI), we examined uropeltid material in the Natural History Museum, London, UK (BMNH), the Muséum national d'Histoire naturelle, Paris, France (MNHN), Museum für Naturkunde, Berlin, Germany (ZMB), Muséum d'Histoire naturelle, Geneva, Switzerland (MHNG), and the Museum of Comparative Zoology, Harvard University, USA (MCZ). For comparative material, particular attention was paid to type specimens of species of Uropeltis having 17 dorsal scale rows at midbody and reported to have more than 200 ventrals: a list of this material is presented in Appendix 1 (including a newly designated lectotype and paralectotypes of Uropeltis nitida). Taxonomy and taxon spellings follow McDiarmid et al. (1999) and Pyron et al. (2016). 
Ventral scale counts were recorded following Gower \& Ablett (2006). Scale row reductions (Appendix 2) were recorded following Dowling (1951). All measures were taken with dial calipers to the nearest $0.1 \mathrm{~mm}$, except for total length and circumference, which were taken to $1 \mathrm{~mm}$ using a ruler and a piece of thread plus ruler, respectively. Snout-vent length was calculated by subtracting tail length from total length. Bilateral measures were taken on the right side of each specimen, unless that side was damaged. All tooth counts were made from wet specimens, these are estimates because it is often not possible to see or feel presence or absence of teeth among gingivae without error. Sex was determined by examining urogenital systems in situ through small ventral incisions in the body wall, or was inferred by examining numbers of subcaudals and/or relative tail length where these exhibited bimodal (presumably sexually dimorphic) variation - those specimens with longer tails being identified as male (see e.g., Wall 1919, 1921; Guibé 1948; Constable 1949; Gower et al. 2008). Following Gower et al. (2008) and Gower \& Maduwage (2011) we made an effort to examine non-traditional characters for uropeltid taxonomy (see Table 1).

Principal components analysis (PCA) was carried out on 24 log-transformed metric variables (Appendix 3) in order to identify major axes of variation and to help formalise the diagnosis of the new species. The PCA included only specimens of species of Uropeltis with 17 dorsal scale rows at midbody and reported to have more than 200 ventrals, and for which we were able to generate data for all 24 characters. PCA was implemented and plots produced using R version 3.3.2 (R Core Team 2016). The raw data used in the PCA are available from the Natural History Museum's data repository (http://data.nhm.ac.uk/dataset/jins_uropeltidae).

Genomic DNA was extracted from a muscle tissue sample of paratype BNHS 3513 (taken from the ethanolfixed voucher prior to its post-fixation in formalin) using Qiagen's DNeasy kit (Qiagen, Valencia, CA). DNA sequence data for parts of the following two mitochondrial $(\mathrm{mt})$ genes were amplified (using the Polymerase Chain Reaction: PCR) and sequenced: 16s rRNA (16s, primers 16Sar-L and 16Sbr-H: Palumbi et al. 1991) and NADH dehydrogenase subunit 4 (nd4, primers ND4 and Leu: Arévalo et al. 1994). Sequences were edited by hand and aligned with publicly available sequences of homologous markers for other uropeltids (Appendix 4); sequences of the additional mt marker, 12s rRNA (12s) were also included (see Appendix 4). Given ongoing doubts about the generic assignment of some uropeltid species (e.g. Pyron et al. 2016: 499) we included all available uropeltid genera in our phylogenetic analyses and not only species of Uropeltis. Alignment was carried out using ClustalW (Thompson et al. 1994) implemented in Geneious v8.1.9 (Biomatters) with default settings (gap open cost $=15$; gap extended cost $=6.66$ ). Ambiguously aligned positions in $12 s$ and $16 s$ alignments were removed using Gblocks v0.91b (Castresana 2000) via an online server (http://phylogeny.fr, Dereeper et al. 2008) using the 'less stringent' option. The final alignment used in analyses included 98 specimens and 1517 nucleotide positions (379 bp [base

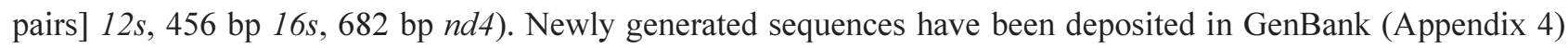
and the analysed alignment is available from the Natural History Museum's data repository (http://data.nhm.ac.uk/ dataset/jins_uropeltidae).

Pairwise uncorrected distances ( $p$-distances) were calculated using MEGA v6.0.6 (Tamura et al. 2013). The concatenated dataset was analysed with PartitionFinder v2.1.1 (Lanfear et al. 2016, Guindon et al. 2010), applying the corrected Aikaike Information Criterion (AICc) to find the best fitting partition scheme and available model(s) of nucleotide substitution to be implemented in subsequent phylogenetic analyses. For models that can be implemented in RAxML v7.2.8 (Stamatakis 2006), GTR $+\mathrm{I}+\mathrm{G}$ is the best fit for four partitions $\left(12 s\right.$ and $n d 41^{\text {st }}$ codon position; $16 s ; n d 43^{\text {rd }}$ position; $n d 42^{\text {nd }}$ position). For models that can be implemented in MrBayes v3.2 (Ronquist et al. 2012), three different models were best fitting for three partitions: $\mathrm{GTR}+\mathrm{I}+\mathrm{G}\left(12 s, 16 s\right.$ and $n d 41^{\text {st }}$ position), GTR $+\mathrm{G}$ (nd4 $3^{\text {rd }}$ position), and $\mathrm{HKY}+\mathrm{I}+\mathrm{G}$ (nd $42^{\text {nd }}$ position).

Phylogenetic relationships for the concatenated dataset were inferred using Bayesian Inference (BI) and Maximum Likelihood (ML). BI analysis was performed in MrBayes v3.2, conducting two independent runs for $1 \times 10^{7}$ generations, sampling every 1,000 generations, resulting in 10,000 trees. Runs were checked using Tracer v1.6.0 (Rambaut et al. 2014) to verify convergence of the runs and that effective sample sizes (ESS) were all $>200$. The first $25 \%$ trees were discarded as burn-in and the remaining trees used to determine posterior probability values for internal branches. ML analysis was performed using RAxML v7.2.8 with the Geneious plugin, using a rapid bootstrapping algorithm and 1,000 bootstrap replicates to quantify support for internal branches. Trees were rooted with Melanophidium, based on evidence that this genus is sister to all other uropeltid genera (Bossuyt et al. 2004, Pyron et al. 2016, Cyriac \& Kodandaramaiah 2017).

The seven type specimens of Uropeltis nitida have 186-196 ventral scales (our data). Constable (1949) 
reported a sample of four U. nitida to have 197-224 ventrals. However, our recent re-examination of Constable's (1949) material indicated that, while these four specimens have 211-226 ventrals (counted using the Gower \& Ablett method), they are clearly not $U$. nitida because they have, for example, scattered pale dots (each on a single scale) on the dorsum (versus largely homogenous dorsum without pale dots) and lacking (versus having) large asymmetric pale patches on the venter. The females (MCZ R-47291 and 47293) have more subcaudals (8 or 9) than in the types of $U$. nitida (5-7, 8 on one side in a single specimen). The MCZ specimens also all lack the contact between the first infralabials and the first ventral that is present in all examined $U$. nitida. We have not thoroughly analysed the MCZ specimens, but they are perhaps more closely allied instead to $U$. ocellata or one of the names currently treated as synonyms of that species (e.g. McDiarmid et al. 1999, Pyron et al. 2016). Uropeltis nitida is here considered to have fewer than 200 ventrals, though the type series was retained in the PCA.

\section{Uropeltis bhupathyi sp. nov.}

(Figs. 1-10; Table 1; Appendices 1-4)

\section{Chresonomy.}

Uropeltis ellioti (Gray, 1858): Kannan \& Bhupathy (1997: 34-34); Mukherjee \& Bhupathy (2004: 109-110); Mukherjee (2007: $23,41,43,51,67,76,77,81,84-85,101,103-104,109-110,115$; figs. 3.4, 5.6; tables 4.4, 5.5, 5.7, 6.2, 6.6; appendices I-II)

Uropeltidae or uropeltid or uropeltids: Mukherjee $(2007: 22,36,39,61,63,73,75$; figs. 3.3, 4.1, 4.3, 5.3, 5.11)

Diagnosis. A Uropeltis with more than 200 ventral scales, 17 dorsal scale rows at midbody and a moderately developed tail shield (tail Type I of Smith 1943: 73) that differs from U. ocellata (and all currently accepted synonyms of that species) in having a substantially longer rostral shield that is $34-41 \%$ (mean 37.5 ) of head length (distance between snout tip and posterior edge of the fourth supralabial) versus $22-31 \%$ (mean 28.4). Uropeltis bhupathyi sp. nov. differs from the only other congener with $>200$ ventrals and 17 dorsal scale rows at midbody, $U$. macrorhyncha, in having a frontal that is wider than long versus longer than wide. The frontal in sampled $U$. macrorhyncha is less than $24 \%$ of head length versus $>30 \%$ in $U$. bhupathyi sp. nov. Even if some $U$. nitida are found to have more than 200 ventrals (see final paragraph of Materials and Methods), the types of that species differ substantially from $U$. bhupathyi sp. nov. in having much shorter rostrals $(27-31 \%$ of head length; mean $=$ $29.8 \%$ ) and pale blotches along the venter. See Fig. 1 for graphical summary of these diagnostic head and head shield features.

The holotype of Uropeltis liura (Günther, 1875) has 183 ventrals (pers. obs.). Rajendran (1985) reported ventral counts ranging from 182-208 in U. liura, though Pyron et al. (2016: 492) questioned whether Rajendran's population was conspecific with topotypic $U$. liura. Whatever the correct identification is, we are confident that the new species described here is not conspecific with Rajendran's U. liura (from the far south of the Western Ghats) because the latter differs from $U$. bhupathyi sp. nov. in lacking lateral stripes anteriorly and in having up to 12 subcaudals, large pale (yellow) patches ventrally forming cross bars, and a relatively shorter rostral.

Holotype. NCBS AU173 (Fig. 2), female based on number of ventrals and relative length of tail (see below). Environs of the campus of the Sálim Ali Centre for Ornithology and Natural History, Anaikatty (sometimes spelled Anaikatti), Coimbatore District, Tamil Nadu, India (11.09 $\mathrm{N}, 76.79^{\circ} \mathrm{E}$, elevation $\left.645 \mathrm{~m}\right)$. Collected 25.xi.2015 by V.J. Jins. See Fig. 3 for map.

Paratopotypes (n = 5). BNHS 3513 (female, collected 26.xi.2015), NCBS AU174 (female, 12.ix.2015), NCBS AU175 (male, 7.xi.2015) collected by V.J. Jins; ZSI/WGRC/IR.V.2899 (female) and BNHS 3514 (male) collected between June 2002 and December 2005 by Debanik Mukherjee.

Referred specimens (n= 3). NCBS AU176 (male, 21.ix.2015), NCBS AU177 (female, 25.ix.2015), and NCBS AU178 (male, 23.xi.2015), all collected by V.J. Jins from the type locality. These specimens are assigned to referred rather than type material because they are damaged, less well preserved and because we have taken a much less substantial set of data for them. We are confident that they are all assignable to U. bhupathyi sp. nov. on the basis that they agree in overall form and colour and have, for example, 206, 213, and 205 ventrals, respectively (Table 1).

Description of holotype. See Table 1 for morphometric and meristic data. Female, based on relatively high number of ventrals, relatively short tail and relatively few subcaudals (see paratype variation section below). Good 
condition, though fixed originally in ethanol and post-fixed in formalin January 2017; ca.10 mm section of body soft ca. $120 \mathrm{~mm}$ anterior to vent.

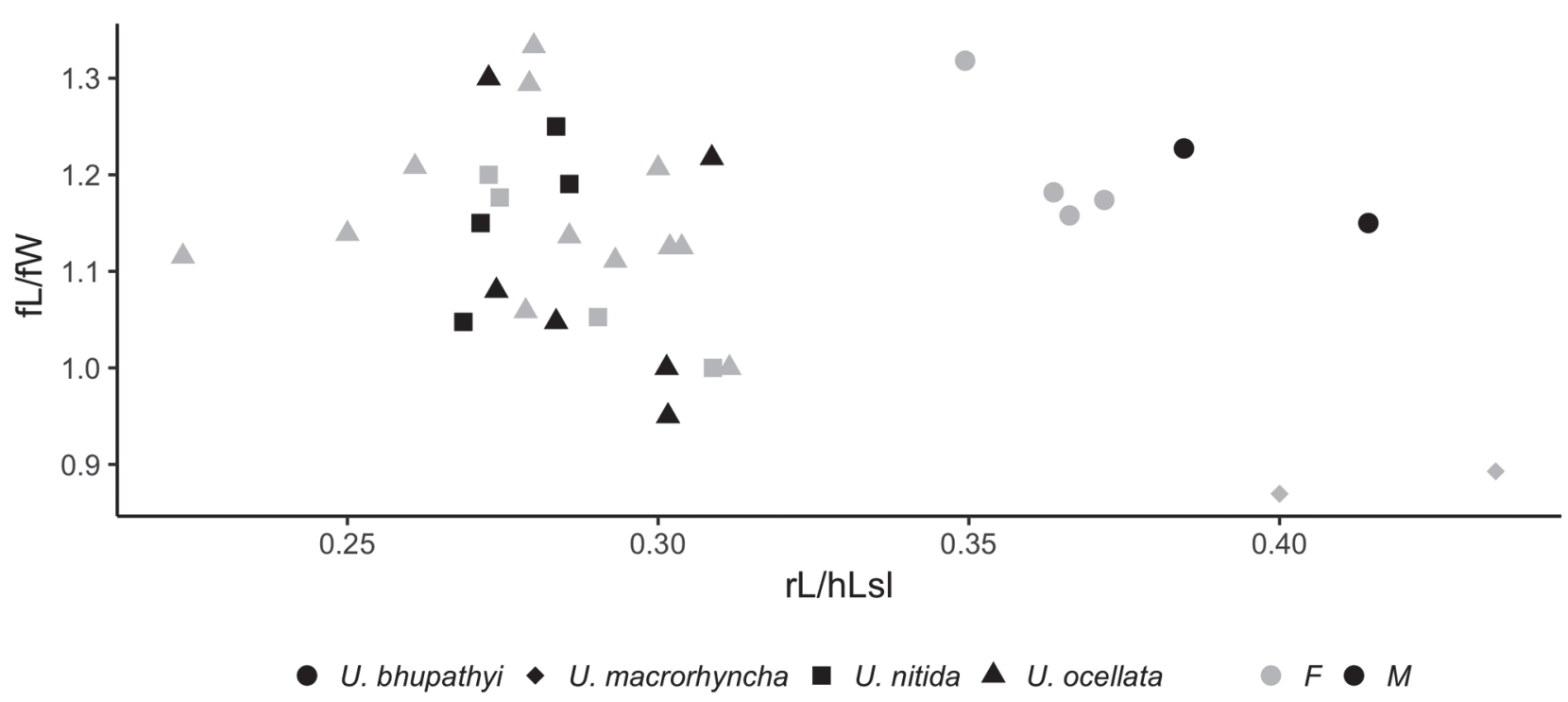

FIGURE 1. Plot of rostral shield length (as a proportion of head length, measured from snout tip to posterior of last supralabial) versus length/width of frontal shield in female and male U. bhupathyi sp. nov. and superficially similar congeners.

Body subcylindrical, slightly wider anteriorly than posteriorly, venter slightly flattened; tapering over c.5 mm immediately behind head; very gently tapering posteriorly up to vent. Head strongly tapering in dorsal view, sides straight to slightly convex, pointed; tapering also in lateral view, gently with straight edges to anterior margin of prefrontal then much more abruptly to tip of rostral, with slightly convex upper margin (i.e., Roman or aquiline nosed).

Rostral pointed, subtrihedral anteriorly; longer than wide in dorsal view, slightly longer than deep in lateral view; dorsally with narrowly rounded longitudinal ridge; at widest slightly in front of and below nostril. Rostral much longer (in dorsal view) than rostral-frontal gap. Frontal kite-shaped, four-sided, though posterolateral edges slightly bent at ocular-parietal contact (so weakly hexagonal); lateralmost edges in contact with oculars strongly diverging anteriorly. Frontal shorter, wider than rostral. Paired nasals in brief contact behind rostral. Midline contact between nasals and between prefrontals (left overlapping right in both cases) subequal in length; midline sutures not parallel with long axis, left prefrontal contacts right nasal but not vice versa. External naris small, subcircular, slightly countersunk within small depression, located in anteroventral corner of undivided nasal shield. Nasal contacts first and second supralabials (SLs). Prefrontal (as nasal) wider than long, shorter than frontal, contacts SL2 and SL3. Supralabials four, SL1 smallest, making least contribution to margin of mouth; SL2 larger than SL1, smaller than SL3; SL4 much the largest and longest. Ocular contacts SL3 and SL4; posterodorsal margin slightly concave. Eye small but distinct, diameter approximately (but not less) than one third length of ocular shield, located near anteroventral corner of ocular; bulges very slightly from ocular surface, pupil appears subcircular; eyes directed anterodorsolaterally.

Paired parietals each about as long as frontal, posteriorly broadly rounded. Opposite parietals in brief midline contact, left overlapping right. Parietals a little longer than wide, wider than frontal and rostral. Each parietal contacts four scales other than head shields. Infralabials (ILs) asymmetric; three on right, IL1 and IL3 subequal in length, notably shorter than IL2; only one IL on left, likely representing a fusion of three ILs based on comparison with right and with other specimens (see Table 1). Left and right first infralabials very briefly in midline contact, separating small, slightly prominent mental from first midline ventral scale. First and second ventrals (in contact) longer than wide, third about as long as wide, fourth (slightly) and subsequent ventrals wider than long.

Nine maxillary teeth on each side (possibly eight on left); mandibular teeth hidden deeper in gingivae, not counted. Teeth simple, pointed, distinctly retrorse, straight, evenly spaced, smallest posteriorly. 


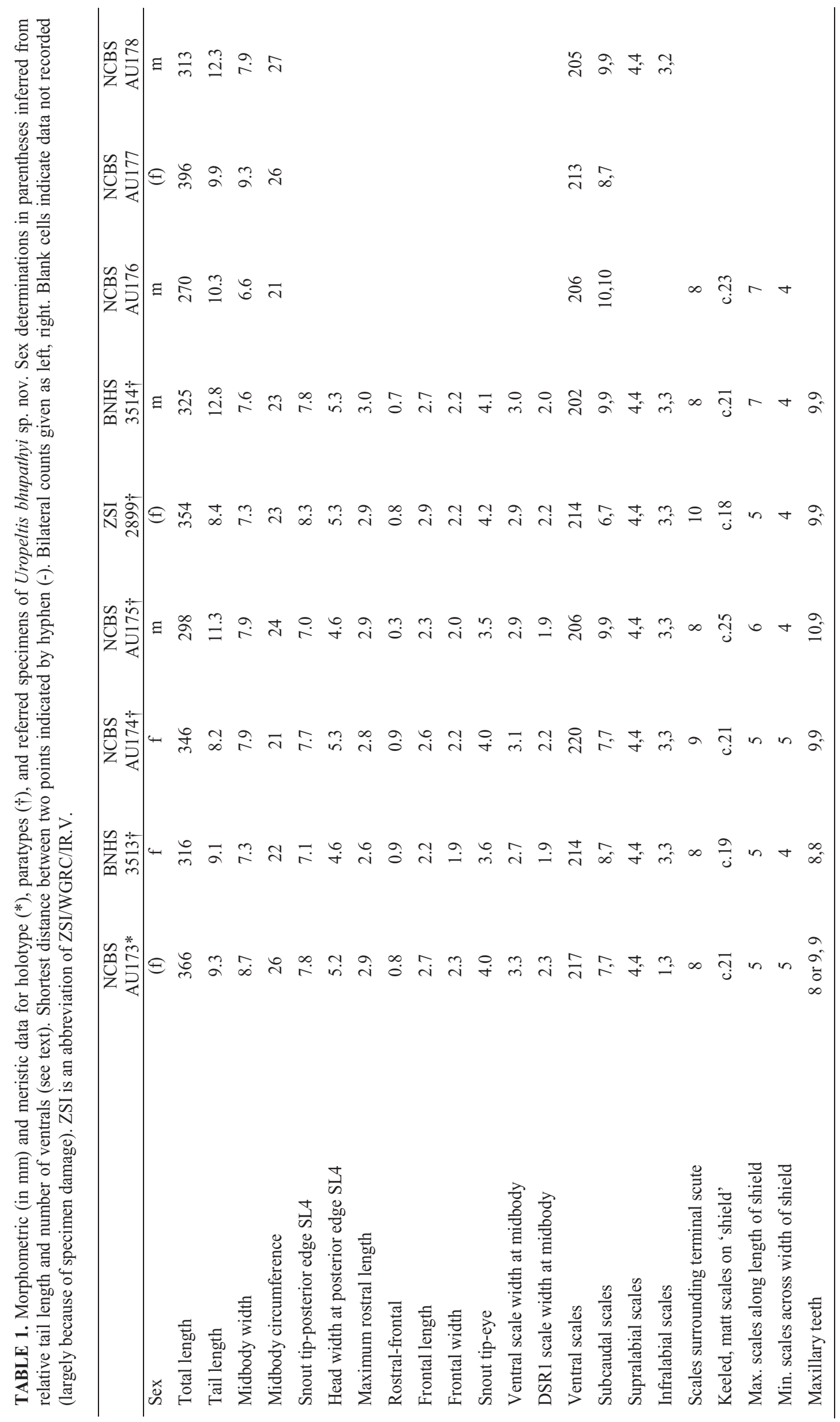



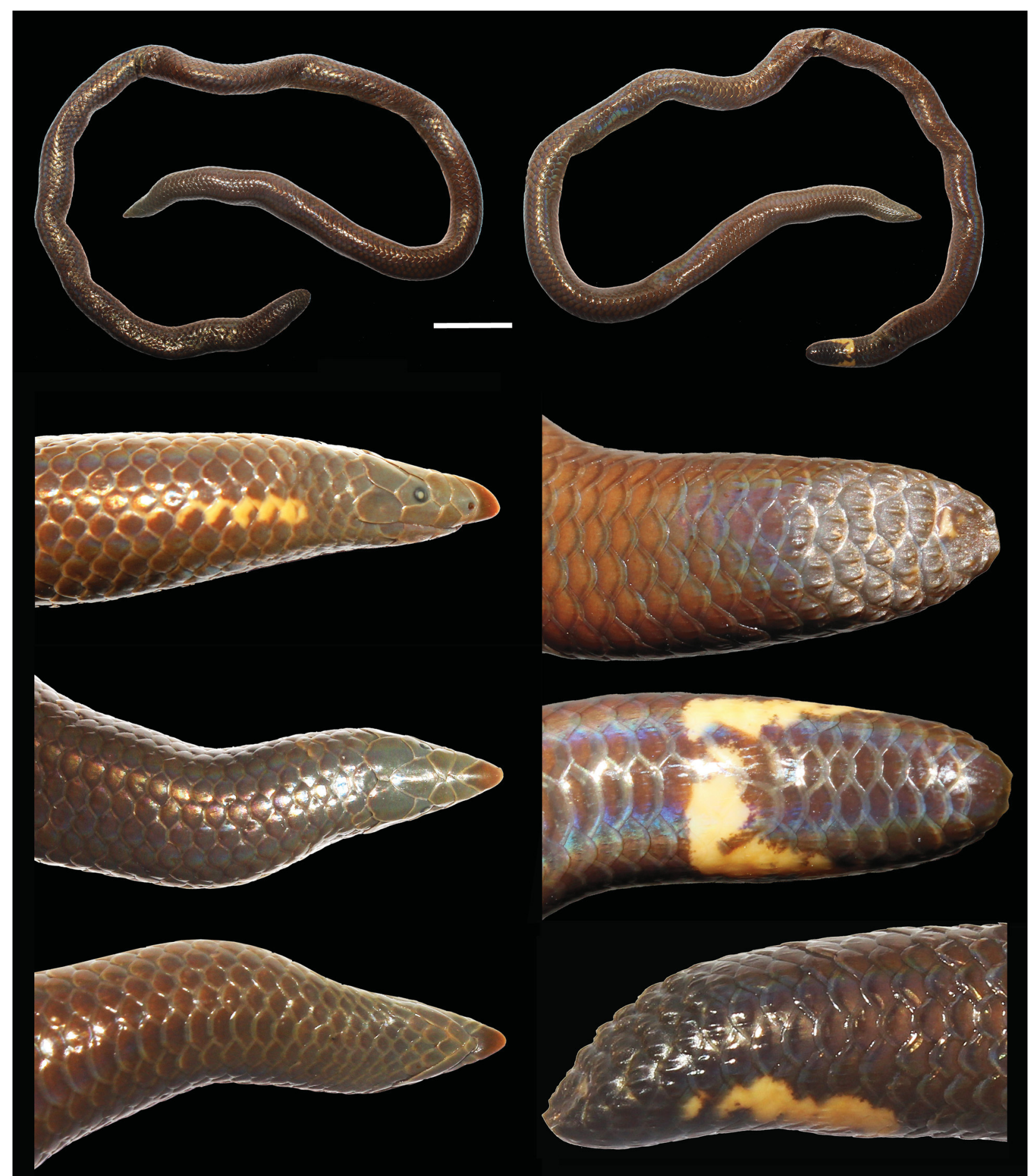

FIGURE 2. Holotype of Uropeltis bhupathyi sp. nov. (NCBS AU173). Upper two images show whole specimen in approximately dorsal (left) and ventral (right) views. Scale bar $(20 \mathrm{~mm})$ applies to left hand image. Left column of lower six images shows head and anterior of body in right lateral (upper), dorsal (central), and ventral (lower) views. Right column of lower six images shows posterior of body and tail in dorsal (upper), ventral (central), and right lateral (lower) views. Lower six images not to scale- see Table 1 for dimensions.

Head and body scales macroscopically smooth, lacking keels, except on far posterior of body and tail. Body scales generally evenly sized on dorsum and along body except for those involved in dorsal scale row reductions. Midline ventral scales between mental and anal of even size though anterior- and posteriormost ones gradually narrow, posteriormost ventral with V-shaped posterior margin (gently rounded in preceding ventrals). Ventrals 217, at midbody approximately 1.4 times as broad as exposed part of adjacent first dorsal scale row. Dorsal scale rows 19 anteriorly (behind head), reducing to 17 along most of body, reducing to 15 immediately in front of vent. 


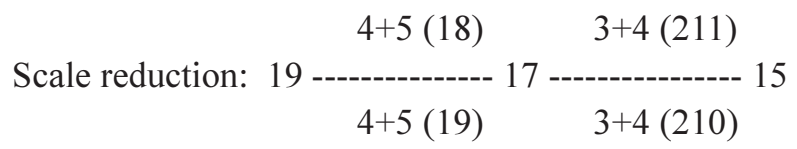

Dorsal scale rows 13 at base of tail. Paired anal scales (right overlying left) considerably larger than posteriormost ventrals and subcaudals. Distal margin of each anal overlaps three other scales in addition to anteriormost subcaudals. Seven subcaudals on each side. Last few dorsal scale row scales on body, ventrals and anals with low but increasingly strong, multiple $(<10$, see Fig. 5), subparallel keels; subcaudals and all other tail scales also keeled. Keels on dorsal scales of body and tail more prominent posteriorly, dorsolaterally. Keels noticeable from approximately one tail length anterior to vent.

Tail shield not sharply demarcated; most closely matching Type I among Smith's (1943) states for Uropeltis tails. More or less flat in central portion but longitudinally convex anterior 'edge' and transversely convex lateral edges. Shield including approximately 21 matt, longitudinally keeled scales, each with 3-5 (6 in one case) keels. Keels more prominent, pointed on second quarter from front; keels lower, more rounded posteriorly; each keel with apex (sometimes pointed) closer to posterior than anterior end of keel, posterior edge straight or slightly convex in lateral view.

Terminal scute wider than long, surrounded by eight scales, including last subcaudals; ventrally convex, smooth (few, very low, short ridges only far laterally and posteromedially); dorsally flat to slightly concave with irregular (though subparallel, anteriorly diverging) ridges and tubercles, more on anterior half. Posterior edge of terminal scute ends in thin, slightly upturned transverse ridge; in dorsal or ventral view with a pair of widely separated $(1.3 \mathrm{~mm})$, paramedian, inconspicuous points; posterior ridge also with inconspicuous curved midline prominence.

In alcohol, background body colour uniform, slightly greyish brown. Body scales iridescent. Each body scale with narrow translucent distal rim immediately beyond narrow, parallel darker line, this line darker brown on dorsalmost nine scale rows than ventrolaterally and ventrally. Head brownish, about as dark as anterior of body, slightly more greyish; fairly uniform (including underside of head) except for paler more tan/yellowish brown rostral; rostral increasingly yellowish, pale anteriorly. Anterior of body with longitudinal, pale yellow narrow lateral line. Line somewhat zigzag, begins level with ninth ventral; occurs mostly on posterodorsal edge of fifth dorsal scale row, less on posteroventral edge of sixth row; extends for approximately eight scales, posteriorly narrower and broken.

Subcaudals brown without pale markings. Tail shield matt, small yellow speck on upper surface of terminal scute; keels, points and tubercles with slightly paler, somewhat translucent distal margins or tips. Approximately U-shaped (pale) yellow marking on underside and ventrolateral surface of tail. Pale marking has irregular transverse bar immediately anterior to vent; yellow on right two thirds of last ventral, right posteromedial edge of preceding (penultimate) ventral, anteromedial quarter of both anals. Pale marking extends posteriorly (and slightly dorsally) as tapering, irregular line, terminating level with posterior margin of fifth subcaudal (three scales anterior to terminal scute). Pale marking on tail unbroken except for left part of transverse bar and right tip.

Variation among paratypes. Condition generally moderate to good. ZSI/WGRC/IR.V.2899 and BNHS 3514 originally formalin fixed, washed and stored in ethanol; BNHS 3513 and NCBS AU174 and AU175 originally ethanol fixed, post-fixed in formalin in February 2017, washed and stored in ethanol. BNHS 3513 and NCBS AU174 and AU175 soft (though NCBS AU174 and AU175 also dehydrated in parts, latter specimen with artefactual longitudinal dorsal ridge); ZSI/WGRC/IR.V.2899 somewhat contorted and posterior third of body soft, BNHS 3514 dehydrated and coiled. Type series is dimorphic with one group having more ventrals, a relatively shorter tail, and fewer subcaudal scales. Two specimens of this group were identified as female through the presence of oviducts and/or ova and two of the contrasting group (fewer ventrals, longer tail, more subcaudals) identified as male based on observations of vas deferens or partially everted hemipenes (Table 1). On that basis, the remaining specimens were sexed based on tail length and number of ventrals. See Fig. 4 for a summary of relative tail length and number of ventrals. 


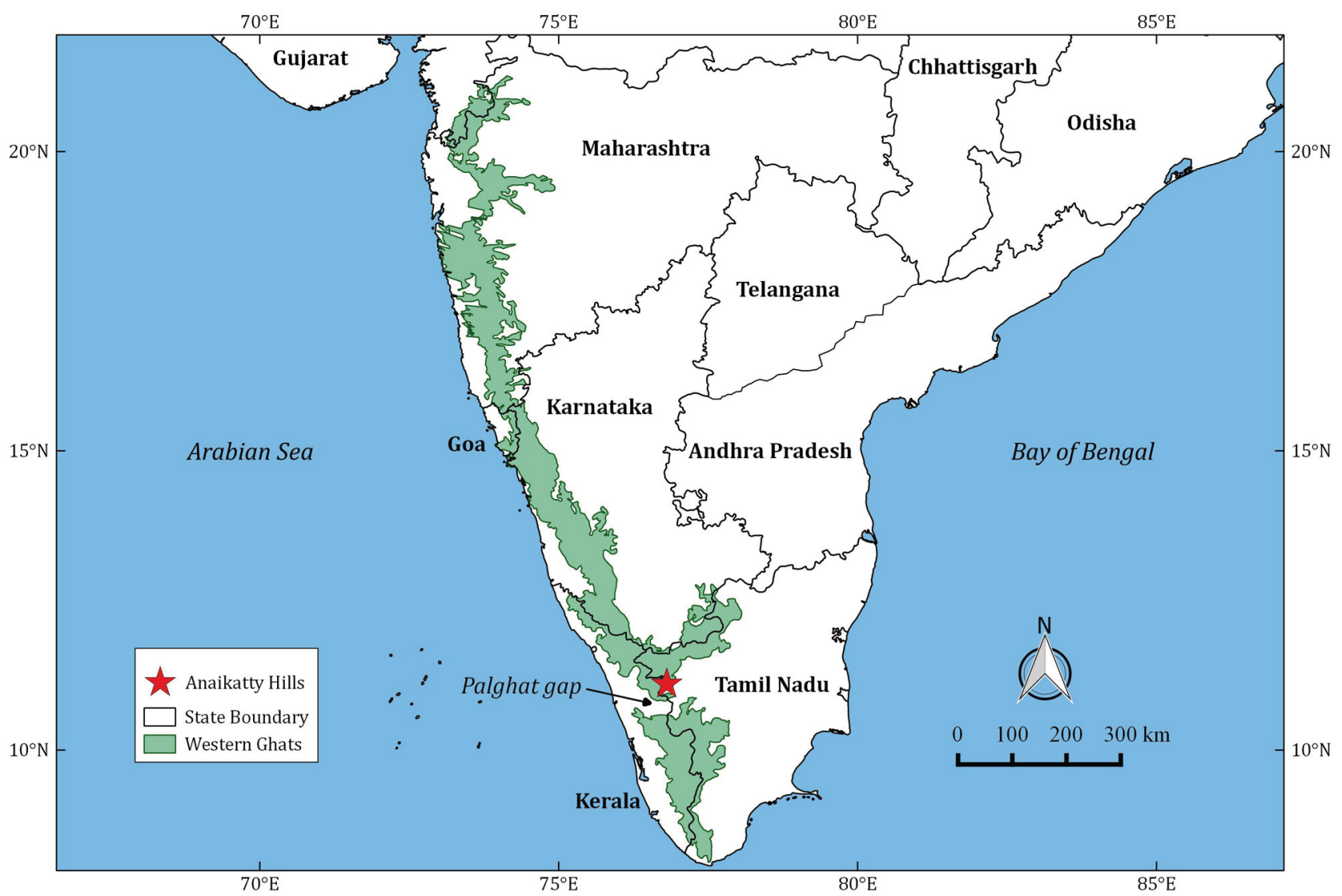

FIGURE 3. Map of peninsular India showing location of type (and only known) locality of Uropeltis bhupathyi sp. nov. (Anaikatty) within the Western Ghats. Ecogeographic boundary of Western Ghats from http://indiabiodiversity.org.

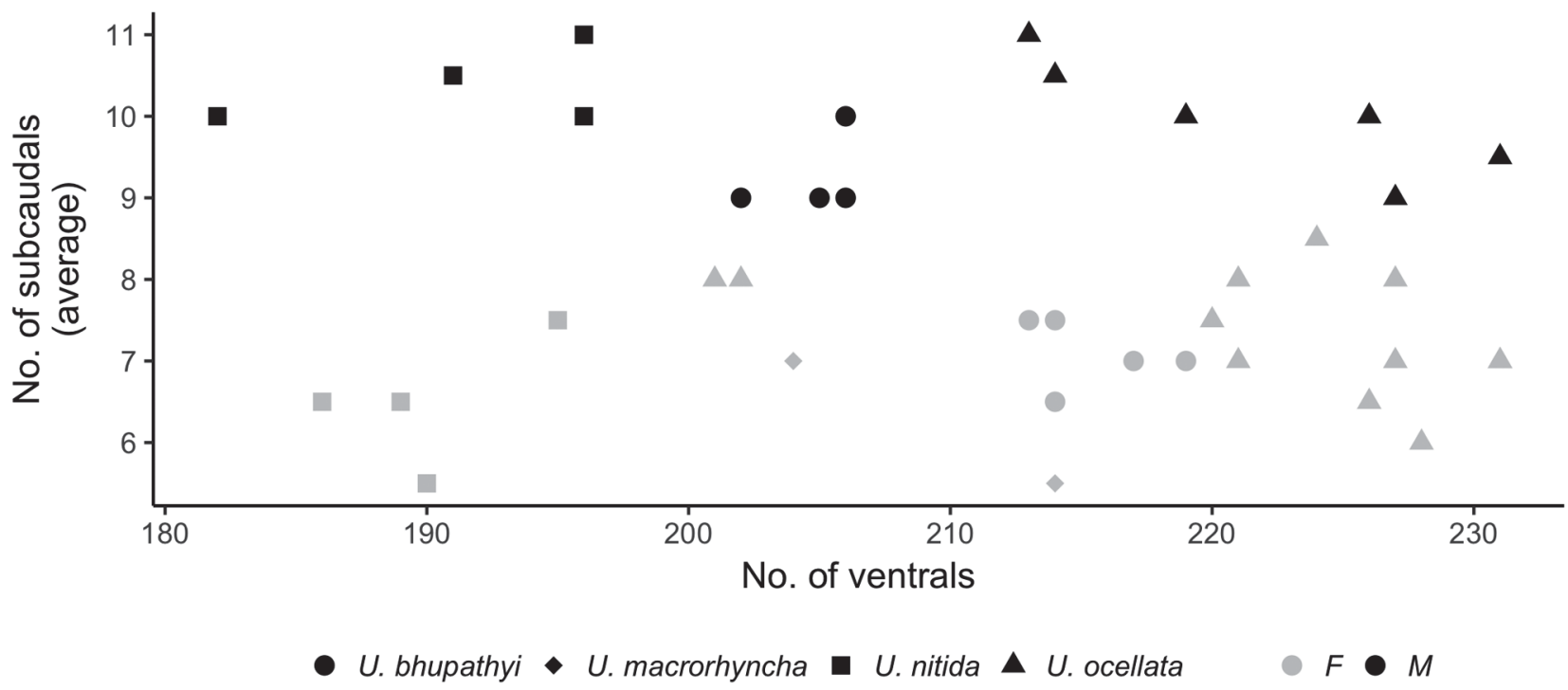

FIGURE 4. Plot summarising variation in number of subcaudals (mean of left and right counts) and number of ventrals in male and female $U$. bhupathyi sp. nov. and superficially similar congeners. See Appendix 1 for list of material examined. 


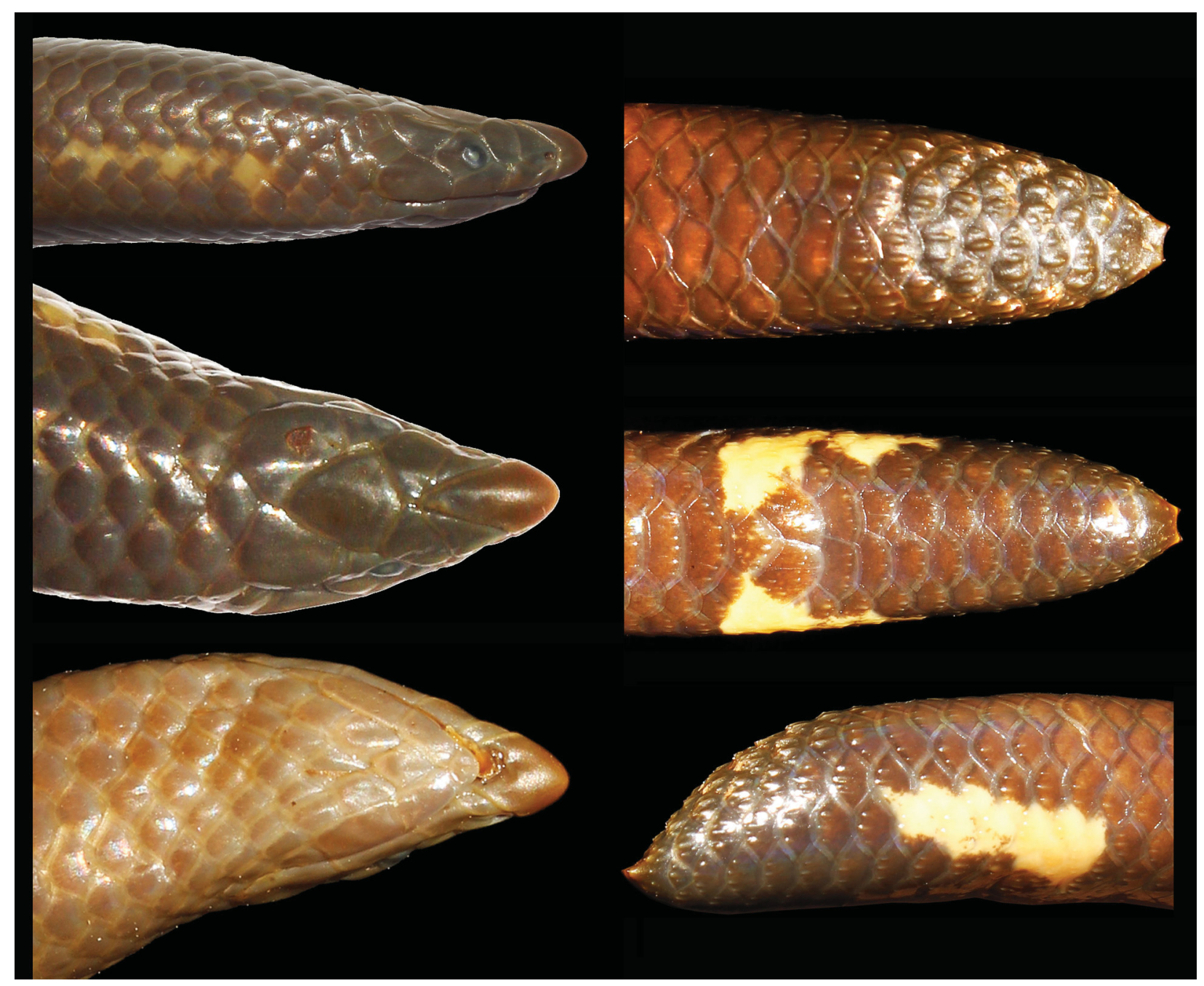

FIGURE 5. Paratype of Uropeltis bhupathyi sp. nov. (NCBS AU175). Left column shows head and anterior of body in right lateral (upper), dorsal (central: note lack of contact between left and right nasal shields), and ventral (lower) views. Right column shows posterior of body and tail in dorsal (upper), ventral (central), and right lateral (lower) views. Images not to scale. See Table 1 for dimensions.

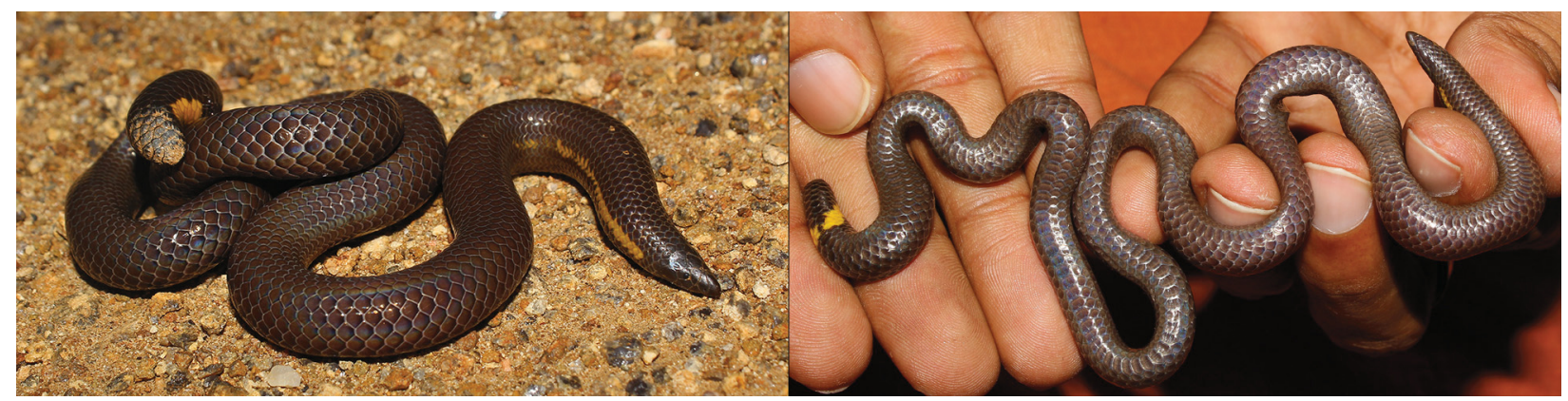

FIGURE 6. Uropeltis bhupathyi sp. nov. in life. Left panel shows uncollected topotypic specimen in left dorsolateral view; right panel shows ventral view of NCBS AU174 prior to preservation. The specimen shown in the left panel was encountered 11 November 2017, and at ca. $400 \mathrm{~mm}$ TL is the largest specimen of the new species seen by the first author. This female (219 ventrals) differs from the type and referred specimens of $U$. bhupathyi sp. nov. in having a thicker and longer lateral yellow stripe.

See Table 1 for details of morphometric and meristic variation. Head shape, number, shape and disposition of shields mostly very similar to holotype; posterior of frontal more rounded in BNHS 3513, rostral contacts prefrontals preventing midline contact between opposite nasals in NCBS AU175 (Fig. 5); infralabials 3,3 in all 
paratypes. Maxillary teeth typically 9,9, seemingly 8,8 in 9112, possibly 10,9 in NCBS AU175. Exposed part of ventrals $1.3-1.5$ as wide as adjacent row of dorsal scales at midbody. Scale row reduction similar to holotype, reducing from 19 to 17 dorsal rows by level with 22 nd ventral and reducing further to 15 rows by level with 4 th to 7 th ventral anterior to vent (see Appendix 2).

Tail notably laterally compressed in NCBS AU175, in which shield more strongly convex (transversely and longitudinally) than holotype (Fig. 5). Shield with approximately 18-25 matt, keeled scales; shield scales with 2-7 keels, these less worn and posteriorly slightly concave in NCBS AU175. Low ridges variable on tail and posterior body scales; absent on ventrals and anals and restricted to posterior of upper part of tail in BNHS 3513 and ZSI/ WGRC/IR.V.2899; on last ventrals and anals but not subcaudals in BNHS 3514, present also on subcaudals in NCBS AU175 (where notably positioned on posterior part of each scale: Fig. 5). Terminal scute with clear ventral ridges in NCBS AU174. Variation in shape of posterior ridge of terminal scute in dorsal/ventral views, with median as well as paramedian projections in BNHS 3513, ZSI/WGRC/IR.V.2899 and BNHS 3514; projections form notably pointed spines in NCBS AU174.

Colour pattern generally consistent; dark with pale lateral lines anteriorly on body and U-shape on underside and sides of tail. Anterior lateral lines as far anteriorly as level with 7th or 8th ventral in all paratypes; extending for as long as 6 to 14 ventrals, often broken and more narrow posteriorly, sometimes more zigzag or herringbone (e.g. BNHS 3513 and BNHS 3514) than in holotype, sometimes encroaching onto 6th dorsal scale row (BNHS 3514) or 4th dorsal scale row (ZSI/WGRC/IR.V.2899). Last (4th) supralabial typically with pale blotches or flecks; isolated pale flecks can also occur on anterior ventrals (ZSI/WGRC/IR.V.2899) or anterior dorsal scales (BNHS 3513).

Pale marking on tail sometimes with broken transverse bar (NCBS AU174 and BNHS 3514); extending to within 2-6 scales from terminal scute, typically extending posterodorsally, more dorsally in NCBS AU174, more horizontal in BNHS 3514. Proximal ends (bases) of dorsal body scales (as well as distal rims) diffusely dark in ZSI/ WGRC/IR.V.2899 and BNHS 3514.

Colour in life. Dark blackish brown dorsally, slightly more charcoal greyish brown ventrally, somewhat metallic and iridescent. Lateral pale stripe on anterior of body and pale marking on tail bright yellow. See Fig. 6 for photographs of two specimens in life.

Etymology. Named in honour of the late Dr. Subramanian Bhupathy (1963-2014) of the Sálim Ali Centre for Ornithology and Natural History, in recognition of his contributions to the appreciation and knowledge of the Indian herpetofauna. Dr. Bhupathy was based on the campus where the type series of the new species was collected, and he published on the existence of this population (Kannan \& Bhupathy 1997; Mukherjee \& Bhupathy 2004). The first author's PhD studies were supervised initially by Dr. Bhupathy. For nomenclatural purposes, the species epithet is considered a noun in apposition.

Suggested common name. Bhupathy's uropeltis or Bhupathy's shieldtail (English).

Distribution, natural history and conservation. Uropeltis bhupathyi sp. nov. is known only from a single locality, the forests of the Anaikatty hills in the vicinity of the campus of the Sálim Ali Centre for Ornithology and Natural History (Fig. 7). The Anaikatty hills are on the leeward (eastern) slopes of the Western Ghats. Their undulating terrain of 600-1,500 $\mathrm{m}$ above mean sea level is characterised by a range of forest types, including (following the classification of Champion \& Seth 1968) mixed dry deciduous (47\%), southern tropical thorny (27\%), tropical semievergreen (8\%) and wet evergreen (2\%) forests, with the foothills (incorporating the type locality of $U$. bhupathyi sp. nov.) dominated by tropical thorny forest or scrub jungle (Mukherjee 2007). Mukherjee (2007) reported the new species (as $U$. ellioti) as the most commonly encountered snake in the Anaikatty hills, recording 25 individuals in the period 2002-2005.

The first author encountered approximately 15 specimens of $U$. bhupathyi sp. nov. at the type locality in 2015 , mostly between September and December, during the Northeast Monsoon. It is hypothesised that, like other known uropeltids (e.g., Rajendran 1985), U. bhupathyi sp. nov. spends a considerable amount of time in soil, but all specimens observed by the first author were seen on the surface in the morning or evening on overcast days, often after or during rainfall. No digging surveys have been undertaken. When picked up, individuals of $U$. bhupathyi sp. nov. are, as is typical for uropeltids, inoffensive, readily entwining around the hand and fingers without attempting to bite.

Three potential threats to the species in its known range are identified. First, individuals have been found as roadkill, especially on the Anaikatty-Coimbatore state highway (at least three individuals). Second, soils in the region are increasingly exploited for the rapidly expanding brick manufacturing industry in the region. Third, in 
2015 the first author observed four or five specimens of $U$. bhupathyi sp. nov. at the type locality with substantially deformed heads and head scales, especially in the mouth region. These animals were alive but barely able to move, and their deformations had the appearance of being inflicted by disease rather than injury (one example shown in Fig. 8). Two of these animals are among the referred specimens documented here (NCBS AU176 and AU177). The precise cause of these deformations is currently unclear, but the potentially lethal "snake fungal disease" reported from North America and Europe causes superficially similar symptoms (Lorch et al. 2016, Franklinos et al. 2017). The environmental preference and tolerance of $U$. bhupathyi sp. nov. is not known, though it might be noted that despite observing multiple individuals during the Northeast monsoon each year between 2012 and 2015, and five in 2017, the first author saw none in 2016, a year with a markedly subdued monsoon (approximately equal effort of general herpetological fieldwork was applied at the type locality in all years).

The type locality of Uropeltis bhupathyi sp. nov. is on the edge of Anaikatty Reserve Forest, part of the Nilgiri Biosphere Reserve, and we expect the species to occur also in this protected area. However, given that the new species is known currently only from a single locality and that little is known about its natural history, it is likely to be initially categorised as Data Deficient in the IUCN Red List of Threatened Species.

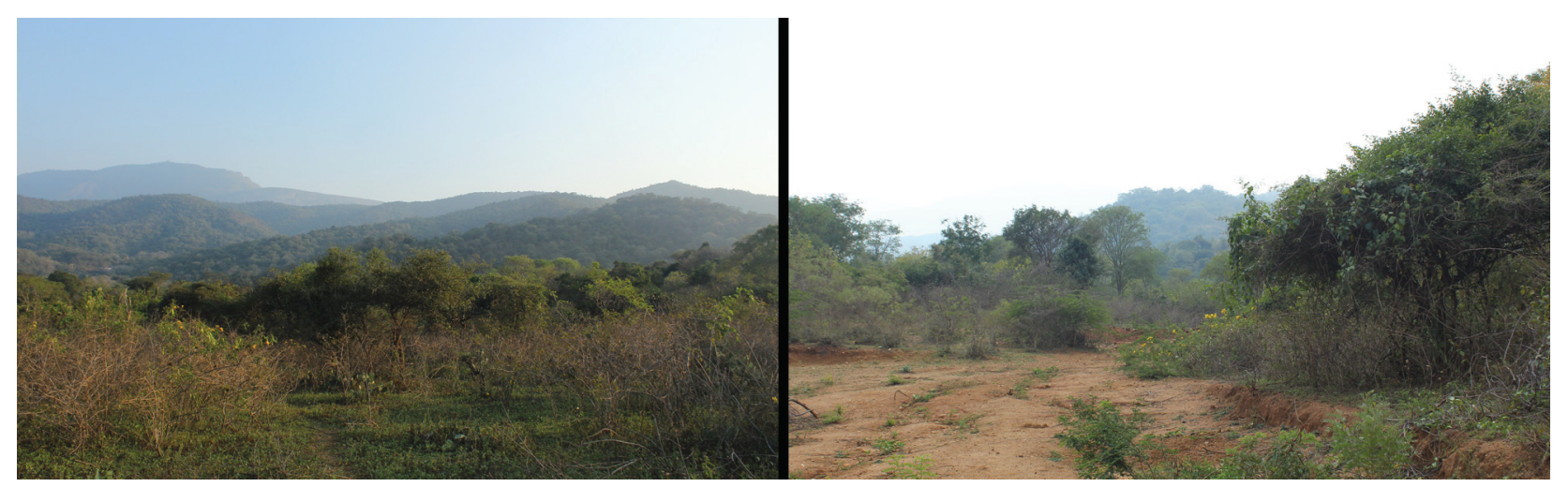

FIGURE 7. Views of habitat at Anaikatty at ca. $650 \mathrm{~m}$ elevation, the type locality of Uropeltis bhupathyi sp. nov.

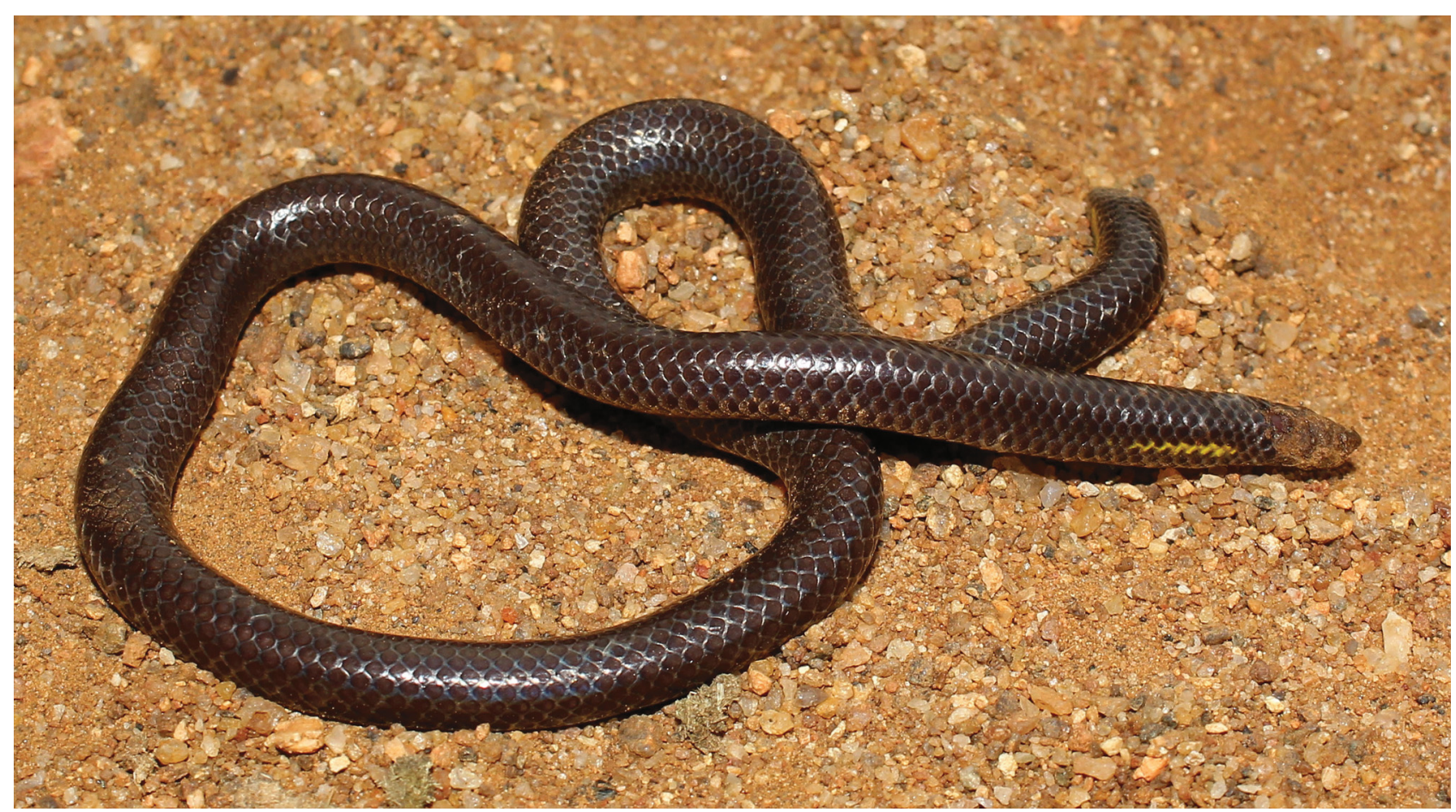

FIGURE 8. Uncollected topotypic specimen of Uropeltis bhupathyi sp. nov. with damaged head, photographed in life on 5 August, 2015. 


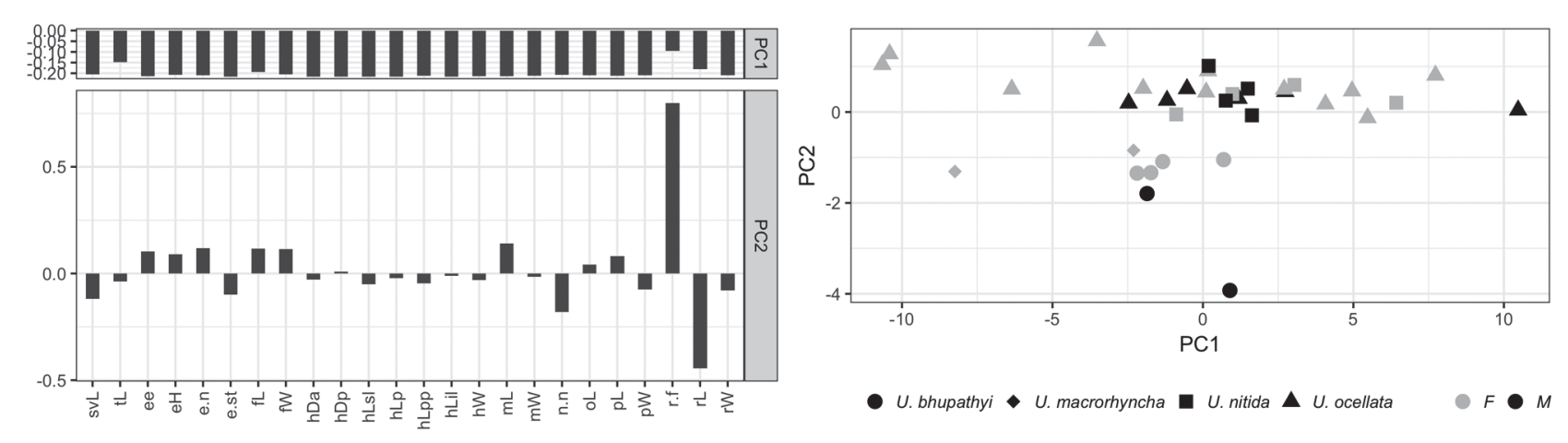

FIGURE 9. Left two panels show the loadings for 24 morphometric characters (see Appendix 3 for explanation of abbreviations) on the first two axes of variation from principal components analysis. Right panel shows PCA morphospace plot for males and females of Uropeltis bhupathyi sp. nov. and three superficially similar congeners.

Quantitative analysis of morphological distinctiveness. The PCA of the log-transformed 24 metric variables found the first two axes to account for $91.63 \%$ of the total variation, these being the only axes with eigenvalues $>1$. The first component (PC1) is strongly associated with size and explains $86.91 \%$ of the variation, with all loadings being of similar magnitude (see Fig. 9). PC2 (4.72\% of variation) has high loadings for rostral-frontal distance ( $\mathrm{r}-$ f), rostral length (rL), and nasal-nasal distance (n-n). In the plot of PC1 versus PC2 (Fig. 9), U. nitida and $U$. ocellata occupy areas of the morphospace with positive values of $\mathrm{PC} 2$, whereas along that axis $U$. bhupathyi sp. nov. and $U$. macrorhyncha occupy areas with negative values. Rostral-frontal distance is relatively shorter for $U$. bhupathyi sp. nov. than the three morphologically similar species in the PCA.

Phylogenetic relationships. None of the relationships moderately or well supported in the BI tree is contradicted by the ML tree and vice versa. In general, the best supported relationships among and within genera are congruent with those well supported relationships recovered by Cyriac \& Kodandaramaiah (2017), who also used the nuclear gene cmos. However, our analyses agreed with those of Bossuyt et al. (2004) and Pyron et al. (2016) rather than Cyriac \& Kodandaramaiah (2017) in recovering Rhinophis as more closely related to Brachyophidium than to Uropeltis. Our analyses recovered Uropeltis bhupathyi sp. nov. nested within the exclusively (based on included samples) Indian uropeltids referred to Uropeltis (Fig. 10). As in Cyriac \& Kodandaramaiah (2017: fig. 1), the basal split within Uropeltis in our trees is between a lineage comprising taxa with more sharply demarcated tail shields (Type II of Smith 1943), including U. macrolepis and U. myhendrae, and a lineage characterised by less strongly demarcated (and less flattened) tail shields (Types I and III of Smith 1943). The latter clade includes all sampled Uropeltis with more than 200 ventral scales, including U. bhupathyi sp. nov. The new species is recovered as sister to Cyriac \& Kodandaramaiah's (2017) $U$. cf. beddomii. The uncorrected pdistance between $U$. bhupathyi sp. nov. and Cyriac \& Kodandaramaiah's (2017) U. cf. beddomii is $1.9 \%$ for $16 \mathrm{~s}$ and $8.3 \%$ for $n d 4$. We have not examined Cyriac \& Kodandaramaiah's (2017) voucher specimens, but $U$. beddomii closely resembles $U$. bhupathyi sp. nov. in having narrow lateral yellow stripes and its tail morphology, though it has pale specks on most ventrals and lower dorsal scale row scales, and has substantially fewer ventrals (181-188 in the three BMNH types). Among taxa sampled for molecular phylogenetics, $U$. bhupathyi sp. nov. and $U$. cf. beddomii are most closely related to Cyriac \& Kodandaramaiah's (2017) U. nitida and U. cf. ochracea-except for $U$. bhupathyi sp. nov. all of these are from the Anaimalai hills, south of the Palghat Gap. Further systematic and biogeographic conclusions for Indian uropeltids are limited by the patchy sampling, non-specific identification of some voucher specimens to date, and our lack of examination of many vouchers of specimens sampled in molecular phylogenies published thus far.

\section{Discussion}

Kannan \& Bhupathy (1997) likely misidentified a specimen of Uropeltis bhupathyi sp. nov. as U. ellioti. Although they reported 20 midbody and only 175 ventrals scales for their specimen, we question the accuracy of these data because uropeltids typically have an odd number of dorsal scale rows at midbody, U. ellioti and U. bhupathyi sp. nov. have 17 dorsal scale rows at midbody, and we know of no other uropeltid species to occur at the type locality 


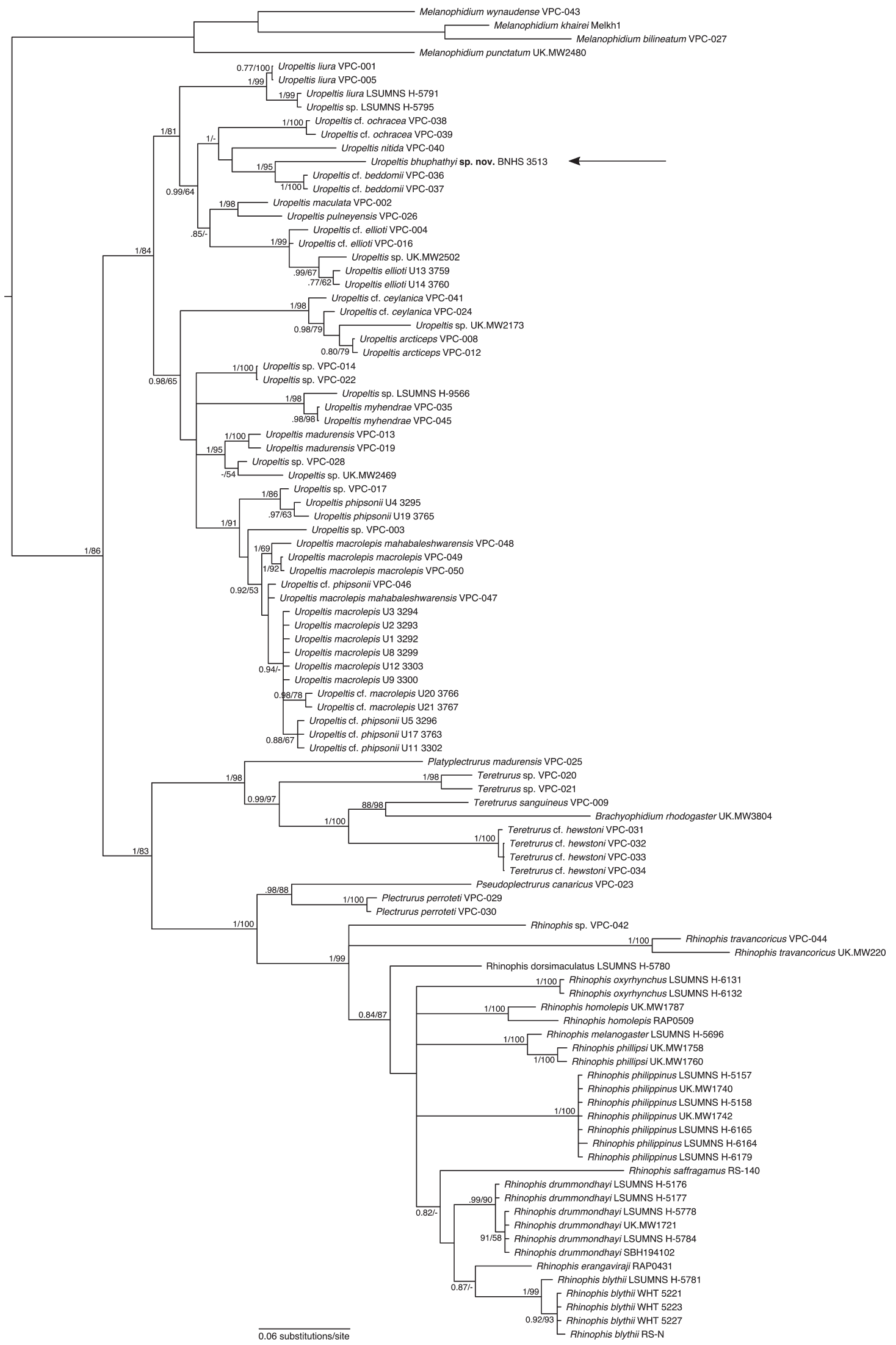

FIGURE 10. Bayesian Inference phylogeny of uropeltid snakes, based on $12 s, 16 s$ and $n d 4$ mitochondrial DNA sequence data, indicating the estimated relationships of $U$. bhupathyi sp. nov. Numbers at internal branches are Bayesian posterior probabilities (left, given to two decimal places) and maximum likelihood bootstrap proportions (right) where these values are at least 0.75 and 50, respectively. See Appendix 4 for specimen details. 
of $U$. bhupathyi sp. nov., the first author having resided and worked there from 2012-present, carrying out many informal herpetological surveys. In addition, Bhupathy told the first author that the subject of Kannan \& Bhupathy's (1997) study was conspecific with some of the material of U. bhupathyi sp. nov. reported here. Two other species of reptiles have been described from the Anaikatty hills this century, the gecko Cnemaspis anaikattiensis Mukherjee, Bhupathy \& Nixon, 2005 (though this was considered a synonym of C. sisparensis (Theobald, 1876) by Manamendra-Arachchi et al. 2007) and the snake Lycodon flavicollis Mukherjee \& Bhupathy, 2007.

Paratype NCBS AU175 is unique among examined U. bhupathyi sp. nov. in that its nasal shields do not make midline contact behind the rostral shield, a character otherwise restricted, among uropeltids, to species of Rhinophis, U. pulneyensis, and some specimens of U. grandis (e.g., Pyron et al. 2016). Pyron et al. (2016) considered the rostral-nasal condition in $U$. pulneyensis, in part, to suggest that this species might be better classified as Rhinophis, but Cyriac \& Kodandaramaiah's (2017) molecular phylogeny rejected that hypothesis and our analyses recover $U$. pulneyensis in the same major clade of Uropeltis as U. bhupathyi sp. nov. but not especially closely related.

In being elongate, having many ventrals, and a relatively prominent rostral, U. bhupathyi sp. nov. is (for a Uropeltis) superficially similar to some species of Rhinophis, including some of the lowland, Dry Zone species such as $R$. dorsimaculatus and $R$. porrectus. The form of other uropeltids and inferred phylogenetic relationships indicates that these similarities are convergent. It is tempting to speculate that this convergence might have a causal link with burrowing in drier soils than the majority of uropeltids (that occur in the hills of the Sri Lankan Wet Zone and in the more western ranges of the Western Ghats), though better environmental and/or functional data and comparative analyses are required to test this. Uropeltis bhupathyi sp. nov. is superficially similar to the poorly known U. macrorhyncha (in shield form, number of ventrals, rostral length and colour pattern) and we expect the two species to be closely related.

The new species is thus far known only from the relatively dry foothills of the leeward slopes of the Western Ghats, with deciduous forests. Such habitats might be considered marginal for Indian uropeltids (e.g. see Rajendran 1985, Pyron et al. 2016) but bear resemblance to some of the drier regions inhabited by some Sri Lankan uropeltids (Rhinophis spp.). Our description of Uropeltis bhupathyi sp. nov. is in line with recent findings of Indian uropeltid diversity in such 'marginal' zones, including from the Eastern Ghats (Aengals \& Ganesh, 2013; Ganesh et al., 2014) and from the northern Western Ghats (Gower et al., 2008, 2016). These recent findings will hopefully encourage dedicated soil surveys in drier areas in peninsular India to better understand uropeltid diversity (see also Aengals \& Ganesh, 2013).

Sexual dimorphism in subcaudal counts and relative tail length has been reported in many (but not all) uropeltid species (e.g., Boulenger 1893; Wall 1919, 1921; Guibé 1948; Constable 1949; Gower et al. 2008, 2016). Although some previous reports have documented sexual dimorphism also in ventral counts in some uropeltid species (e.g. Wall 1919, 1921), this phenomenon is rarely recognised (e.g., Pyron et al. 2016: 459). The report here of sexually dimorphic ventral counts in $U$. bhupathyi sp. nov. but not $U$. nitida (and the lack of dimorphism in the species examined by Guibé 1948) suggests that interpretation of ventral counts for taxonomy is non-trivial but can be aided by identification of the sex of specimens. The higher number of ventrals in females, where this occurs, is presumably linked to selective pressure for increased space for foetal gestation, all uropeltids being viviparous as far as is known (e.g., Rajendran 1985).

\section{Acknowledgements}

This research was funded, in part, by awards to V.J. Jins from the Student Conference on Conservation Science (SCCS Cambridge UK, with special thanks to Shireen Green). F.L. Sampaio's contribution was supported by a London NERC DTP studentship (supervised by D.J.G and J.J. Day) and an award from the Systematics Association and Linnean Society's Systematics Research Fund. D.J.G. and F.L.S's visits to MNHN and ZMB were funded by grants from the EU SYNTHESYS project. D.J.G. and V.J.J. thank Ramachandran Kotharambath (Central University Kerala) for hosting a visit in 2017, and staff at NCBS (Varad Giri), BNHS (Rahul Khot), ZSI (Jafer Palot), MNHN (Nicolas Vidal and colleagues), ZMB (Frank Tillack and Mark-Oliver Rödel), MHNG (Andreas Schmitz), and MCZ (José Rosado) for accessioning and/or providing access to specimens. V.J.J. thanks 
Rajan Pilakandy for help preparing plates, and the Director of SACON for institutional support. We thank Ashok Captain, Vivek Phillip Cyriac, S.R. Ganesh, Varad Giri and Ullasa Kodandaramaiah for discussions about Indian uropeltid biology. S.R. Ganesh provided constructive criticism of the submitted manuscript. The authors are extremely grateful to V. Deepak for help in generating DNA sequence data.

\section{References}

Aengals, R. \& Ganesh, S.R. (2013) Rhinophis goweri-a new species of shieldtail snake from the Southern Eastern Ghats, India. Russian Journal of Herpetology, 20 (1), 61-65.

Arévalo, E., Davis, S.K. \& Sites, J.W. (1994) Mitochondrial DNA sequence divergence and phylogenetic relationships among eight chromosome races of the Sceloporous grammicus complex (Phyrynosomatidae) in central Mexico. Systematic Biology, 43, 387-418. https://doi.org/10.1093/sysbio/43.3.387

Bossuyt, F., Meegaskumbura, M., Beenaerts, N., Gower, D.J., Pethiyagoda, R., Roelants, K., Mannaert, A., Wilkinson, M., Bahir, M.M., Manamendra-Arachchi, K. \& Ng, P.K. (2004) Local endemism within the Western Ghats-Sri Lanka biodiversity hotspot. Science, 306 (5695), 479-481.

Boulenger, G.A. (1893) Catalogue of the snakes in the British Museum (Natural History). Vol. I. containing the families Typhlopidae, Glauconiidae, Boidae, Ilysiidae, Uropeltidae, Xenopeltidae and Colubridae aglyphae. Part. British Museum (Natural History), London, $448 \mathrm{pp}$.

Castresana, J. (2000) Selection of conserved blocks from multiple alignments for their use in phylogenetic analysis. Molecular Biology and Evolution, 17 (4), 540-552. https://doi.org/10.1093/oxfordjournals.molbev.a026334

Champion, H.G. \& Seth, S.K. (1968) A revised survey of the forest types of India. Government of India Press, Nasik, 404 pp.

Chettri, B. \& Bhupathy, S. (2010) Three little known reptile species from the Araku Valley, Eastern Ghats with notes on their distribution. Journal of Threatened Taxa, 2 (8), 1109-1113. https://doi.org/10.11609/JoTT.o2329.1109-13

Constable, J.D. (1949) Reptiles from the Indian Peninsula in the Museum of Comparative Zoology. Bulletin of the Museum of Comparative Zoology, 103, 59-160.

Cyriac, V.P. \& Kodandaramaiah, U. (2017). Paleoclimate determines diversification patterns in the fossorial snake family Uropeltidae Cuvier, 1829. Molecular Phylogenetics and Evolution, 116, 97-107. https://doi.org/10.1016/j.ympev.2017.08.017

Dereeper, A., Guignon, V., Blanc, G., Audic, S., Buffet, S., Chevenet, F., Dufayard, J.F., Guindon, S., Lefort, V., Lescot, M. \& Claverie, J.M. (2008) Phylogeny.fr: robust phylogenetic analysis for the non-specialist. Nucleic acids research, 36 (Supplement 2), W465-W469.

Dowling, H.G. (1951) A proposed method of expressing scale reductions in snakes. Copeia, 1951, 131-134. https://doi.org/10.2307/1437542

Franklinos, L.H.V., Lorch, J.M., Bohuski, E., Rodriguez-Ramos Fernandez, J., Wright, O.N., Fitzpatrick, L., Petrovan, S., Durrant, C., Linton, C., Baláž, V., Cunningham, A.A. \& Lawson, B. (2017) Emerging fungal pathogen Ophidiomyces ophiodiicola in wild European snakes. Scientific Reports, 7, 3844. https://doi.org/10.1038/s41598-017-03352-1

Ganesh, S.R., Aengals, R. \& Ramanujam, E. (2014) Taxonomic reassessment of two Indian shieldtail snakes in the Uropeltis ceylanicus species group (Reptilia: Uropeltidae). Journal of Threatened Taxa, 6 (1), 5305-5314. https://doi.org/10.11609/JoTT.o3636.5305-14

Ganesh, S.R. \& Arumugam, M. (2016) Species richness of montane herpetofauna of Southern Eastern Ghats, India: a historical resume and a descriptive checklist. Russian Journal of Herpetology, 23 (1), 7-24.

Gans C. (1966) List und der rezenten Reptilian und Amphibian. Uropeltidae. Das Tierreich, 84, 1-29.

Gower, D.J. \& Ablett, J.D. (2006) Counting ventral scales in Asian aniloid snakes. Herpetological Journal, 16, $259-263$.

Gower, D.J. \& Maduwage, K. (2011) Two new species of Rhinophis Hemprich (Serpentes: Uropeltidae) from Sri Lanka. Zootaxa, 2881, 51-68.

Gower, D.J., Captain, A. \& Thakur, S.S. (2008) On the taxonomic status of Uropeltis bicatenata (Günther) (Reptilia: Serpentes: Uropeltidae). Hamadryad, 33, 64-82.

Guibé, J. (1948) Étude du dimorphisme sexuel chez trois espèces du genre Silybura (Ophidien). Bulletin de la Societé zoologique de France, 73, 91-94.

Guindon, S., Dufayard, J.F., Lefort, V., Anisimova, M., Hordijk, W. \& Gascuel, O. (2010) New algorithms and methods to estimate maximum-likelihood phylogenies: assessing the performance of PhyML 3.0. Systematic Biology, 59 (3), $307-321$. https://doi.org/10.1093/sysbio/syq010

Günther, A. (1862) On new species of snakes in the collection of the British Museum. Annals and Magazine of Natural History, Series 3, 9, 52-59. 
Kannan, P. \& Bhupathy, S. (1997) Occurrence of the Elliot's shieldtail snake Uropeltis ellioti in Anaikatty Hills, Nilgiri Biosphere Reserve. Cobra, 28, 34-35.

Lanfear, R., Frandsen, P.B., Wright, A.M., Senfeld, T. \& Calcott, B. (2016) PartitionFinder 2: new methods for selecting partitioned models of evolution for molecular and morphological phylogenetic analyses. Molecular Biology and Evolution, 34 (3), 772-773.

https://doi.org/10.1093/molbev/msw260

Lorch, J.M, Knowles, S., Lankton, J.S., Michell, K., Edward, J.L., Kapfer, J.M., Staffen, R.A., Wild, E.R., Schmidt, K.Z., Ballman, A.E., Blodgett, D., Farrell, T.M., Glorioso, B.M., Last, L.A., Price, S.J., Schuler, K.L., Smith, C.E., Wellehan, J.F.X. \& Blehert, D.S. (2016) Snake fungal disease: an emerging threat to wild snakes. Philosophical Transactions of the Royal Society of London B, 371, 20150457. https://doi.org/10.1098/rstb.2015.0457

Manamendra-Arachchi, K., Batuwita, S. \& Pethiyagoda, R. (2007) A taxonomic revision of the Sri Lankan day-geckos (Reptilia: Gekkonidae: Cnemaspis), with description of new species from Sri Lanka and southern India. Zeylanica, 7 (1), 9-122.

McDiarmid, R., Campbell, J.A. \& Touré, T. (1999) Snake Species of the World. A Taxonomic and Geographic Reference. Vol. 1. The Herpetologists' League, Washington, $511 \mathrm{pp.}$

Mukherjee, D. \& Bhupathy, S. (2004) Uropeltis ellioti in the diet of Naja naja. Hamadryad, 28, 109-110.

Mukherjee, D. (2007) Resource utilization patterns of reptiles in the tropical dry mixed deciduous forest of Anaikatty Hills, Western Ghats, India. Unpublished Ph.D. Dissertation, Bharathiar University, Coimbatore, 151 pp.

Palumbi, S., Martin, A., Romano, S. McMillan, W.O., Stice, L. \& Grabowski, G. (1991) The simple fool's guide to PCR. Version 2.0. Special Publication of the Department of Zoology, University of Hawaii, Honolulu, $47 \mathrm{pp}$.

Pyron, R.A., Ganesh, S.R., Sayyed, A., Sharma, V., Wallach, V. \& Somaweera, R. (2016) A catalogue and systematic overview of the shield-tailed snakes (Serpentes: Uropeltidae). Zoosystema, 38, 453-506. https://doi.org/10.5252/z2016n4a2

R Core Team (2016) R: A language and environment for statistical computing. R Foundation for Statistical Computing, Vienna. Available from: http://www.R-project.org/ (accessed 28 February 2018)

Rajendran, M.V. (1985) Studies in uropeltid snakes. Madurai Kamaraj University, Madurai, 132 pp.

Rambaut, A., Suchard, M., Xie, W. \& Drummond, A. (2014) Tracer v. 1.6. Institute of Evolutionary Biology, University of Edinburgh. [software]

Ronquist, F., Teslenko, M., Van Der Mark, P., Ayres, D.L., Darling, A., Höhna, S., Larget, B., Liu, L., Suchard, M.A. \& Huelsenbeck, J.P. (2012) MrBayes 3.2: efficient Bayesian phylogenetic inference and model choice across a large model space. Systematic Biology, 61 (3), 539-542.

Smith, M.A. (1943) The fauna of British India, Ceylon and Burma, including the whole of the Indo-Chinese Sub-Region. Reptilia and Amphibia. Vol. 3. Serpentes. Taylor and Francis, London, 583 pp.

Stamatakis, A. (2006) RAxML-VI-HPC: maximum likelihood-based phylogenetic analyses with thousands of taxa and mixed models. Bioinformatics, 22 (21), 2688-2690. https://doi.org/10.1093/bioinformatics/btl446

Tamura, K., Stecher, G., Peterson, D., Filipski, A. \& Kumar, S. (2013) MEGA6: molecular evolutionary genetics analysis version 6.0. Molecular Biology and Evolution, 30 (12), 2725-2729. https://doi.org/10.1093/molbev/mst197

Thompson, J.D., Higgins, D.G. \& Gibson, T.J. (1994) CLUSTAL W: improving the sensitivity of progressive multiple sequence alignment through sequence weighting, position-specific gap penalties and weight matrix choice. Nucleic Acids Research, 22 (22), 4673-4680. https://doi.org/10.1093/nar/22.22.4673

Wall, F. (1919) Notes on a collection of snakes made in the Nilgiri hills and adjacent Wynaad. Journal of the Bombay Natural History Society, 26, 552-584.

Wall, F. (1921) Ophidia Taprobanica or the snakes of Ceylon. H. R. Cottle, Colombo, 582 pp.

\section{Note added in proof}

Eight additional specimens of Uropeltis nitida have recently been identified in the California Academy of Sciences, San Francisco, USA (CAS 244473, 244476-8, 244480-3, all from the vicinity of Malakkapara, Anaimalai hills). These have ventral counts of 195-211 but their head scales and colour pattern much more closely resemble the types of $U$. nitida than of $U$. bhupathyi. D.J.G. thanks Lauren Scheinberg and Erica Ely for access to CAS specimens. 
APPENDIX 1. Comparative material examined.

(a) Specimens used in quantitative morphological analyses

Specimen numbers have the following prefixes:

BMNH Natural History Museum, London, UK

MCZ Museum of Comparative Zoology, Harvard University, USA

MHNG Muséum d'histoire naturelle, Geneva, Switzerland

MNHN Muséum d'histoire naturelle, Paris, France

NMW Naturhistorisches Museum, Vienna, Austria

ZMB Museum für Naturkunde, Berlin, Germany

\section{Uropeltis bhupathyi sp. nov.}

All type and referred specimens reported in this paper.

\section{Uropeltis macrorhyncha (Beddome, 1877)}

BMNH 1946.9.7.45 [previously 83.1.12.24]: holotype

MHNG 845.13

\section{Uropeltis nitida (Beddome, 1878)}

Pyron et al. (2016) considered the species to be known only from the seven syntypes (ignoring NMW 21597 mentioned by McDiarmid et al. (1999)), but we additionally report ZMB 10351 as a member of this species. We designate a lectotype and six paralectotypes from the type series, selecting the lectotype on the basis of it being well preserved and having been scored for meristic and metric charcaters in this study.

BMNH 1946.1.16.31 [previously 78.1.11.1 or 2]: lectotype of Uropeltis nitida (Beddome, 1878) (designated here)

BMNH 1946.1.13.95, 96 \& 97 [previously 83.1.12.38, 39 \& 40]: paralectotypes of Uropeltis nitida (Beddome, 1878) (designated here)

BMNH 1946.1.16.30 [previously 78.1.11.1 or 2] paralectotype of Uropeltis nitida (Beddome, 1878) (designated here)

MNHN 1895.87 (two specimens, informally a and b) paralectotypes of Uropeltis nitida (Beddome, 1878) (designated here)

ZMB 10351

\section{Uropeltis ocellata (Beddome, 1863)}

We included in our study all specimens previously considered as possible types of U. ocellata and its two currently considered synonyms, U. dupeni and U. ochracea. See Gans (1966), McDiarmid et al. (1999) and Pyron et al. (2016) for further discussion of the identity of the types. Several jars in the BMNH collection contain specimens identified as types of ocellata or ochracea, though several also bear label annotations indicating that they are probably not Beddome's types.

BMNH 1946.1.15.59 (lectotype of Silybura ocellata Beddome, 1863: see Gans (1966))

BMNH 1946.1.15.42 [previously 83.1.12.25] (holotype of Silybura dupeni Beddome, 1878)

BMNH 1946.1.15.43 [previously 83.1.12.41] (a type of Silybura ochracea Beddome, 1878)

BMNH 1946.1.15.44 \& 45 [previously 83.1.12.42 \& 43] (types of Silybura ochracea Beddome, 1878)

BMNH 1946 1.2.30 \& 31 [previously 83.1.12.44 \& 45] (types of Silybura ochracea Beddome, 1878)

BMNH 1946 1.15.69, 70 \& 71 [previously 83.1.12.46, $47 \&$ 48] (types of Silybura ochracea Beddome, 1878)

BMNH 1946.1.15.85 \& 86 [previously 80.11.24.3 \& 4] (previously considered possible types of Silybura ocellata Beddome, 1863)

MNHN 1895.83 (paralectotype of Silybura ocellata Beddome, 1863: see Gans (1966), McDiarmid et al. (1999) and Pyron et al. (2016))

MNHN 1895.84 (two specimens; paralectotypes of Silybura ocellata Beddome, 1863: see Gans (1966), McDiarmid et al. (1999) and Pyron et al. (2016))

ZMB 10355

ZMB 10342 (two specimens, informally a and b)

\section{(b) Other specimens examined}

MCZ R-47290-93: specimens reported erroneously by Constable (1949) to be Uropeltis nitida.

MCZ R-47288-89, R-3872, R-3873, and R-3884: specimens reported by Constable (1949) to be U. ocellata.

BMNH 1946.1.16.7 [previously 74.4.29.1206]: holotype of Uropeltis liura

BMNH 1946.1.16.13, 17 \& 18 [previous number unclear, jar states “61.12.30.8 30-68?” but accession register entries are not precise enough to clarify this]: types of Uropeltis beddomii

MNHN 1895.90 (two specimens): reported as possible types of Uropeltis beddomii by Pyron et al. (2016: 489) but Günther (1862) mentions only three specimens in his original description, these likely being the three BMNH specimens. 


\section{APPENDIX 2}

Dorsal scale row reductions in holotype (*) and paratypes (all other specimens) of Uropeltis bhupathyi sp. nov.

\begin{tabular}{|c|c|c|}
\hline \multirow{3}{*}{ NCBS AU173*: } & $4+5(18)$ & $3+4(211)$ \\
\hline & \multicolumn{2}{|c|}{19 --------------- 17 ---------------- 15} \\
\hline & $4+5(19)$ & $3+4(210)$ \\
\hline \multirow{3}{*}{ BNHS 3513: } & $3+4(22)$ & $1+2(208)$ \\
\hline & \multicolumn{2}{|c|}{19 --------------- 17 ---------------- 15} \\
\hline & $3+4(16)$ & $3+4(211)$ \\
\hline \multirow{3}{*}{ NCBS AU174: } & $4+5(20)$ & $3+4(215)$ \\
\hline & \multicolumn{2}{|c|}{19 -------------- 17 --------------- 15} \\
\hline & $4+5(21)$ & $4+5(214)$ \\
\hline \multirow{3}{*}{ NCBS AU175: } & $4+5(20)$ & $3+4(201)$ \\
\hline & \multicolumn{2}{|c|}{19 --------------- 17 ---------------- 15} \\
\hline & $4+5(16)$ & $3+4(203)$ \\
\hline \multirow{2}{*}{\multicolumn{3}{|c|}{ ZSI/WGRC/IR.V.2899: 19 - }} \\
\hline & & \\
\hline & $3+4(16)$ & $3+4(209)$ \\
\hline \multirow[b]{2}{*}{ BNHS 3514: } & $6+7(19)$ & $3+4(197)$ \\
\hline & 19 ----------- 17 & ----------- 15 \\
\hline
\end{tabular}

\section{APPENDIX 3}

Morphometric characters (and their abbreviations) used in Principal Component Analysis. Hyphen (-) denotes shortest distance between two structures.

ee eye-eye centres (distance between centres of eyes)

eH eye height (transverse distance between centre of eye and lip, i.e. lower edge of supralabial)

e-n eye-naris

e-st eye-snout tip

fL frontal greatest length

fW frontal greatest width

hDa head depth anteriorly (distance between anterior end of frontal and upper lip at point of contact between second and third supralabials)

hDp head depth posteriorly (transverse distance between midline suture between parietal shields and lower edge of posteriormost supralabial)

hLsl head length 1 (distance between tip of rostral and posterior edge of posteriormost supralabial)

hLp head length 2 (distance between tip of rostral and posteriormost end of parietal)

hLpp head length 3 (distance between tip of rostral and posterior end of midline suture between parietal shields)

hLil head length 4 (distance between tip of rostral and posterior end of posteriormost infralabial)

hW head width (distance between posterior edges of posteriormost supralabials)

mL mandible length (distance between posterior edge of posteriormost infralabial and tip of mental)

$\mathbf{m W}$ mouth width (distance between posterior edges of posteriormost infralabials)

n-n naris-naris (shortest distance between nares)

oL ocular greatest length

pL parietal greatest length

pW parietal width (distance between posteriormost end of frontal-parietal contact and lateralmost end of parietal-ocular contact)

r-f rostral-frontal (gap between frontal and rostral)

rL rostral greatest length

rW rostral greatest width

svL snout-vent length

tL tail length (vent-tail tip) 


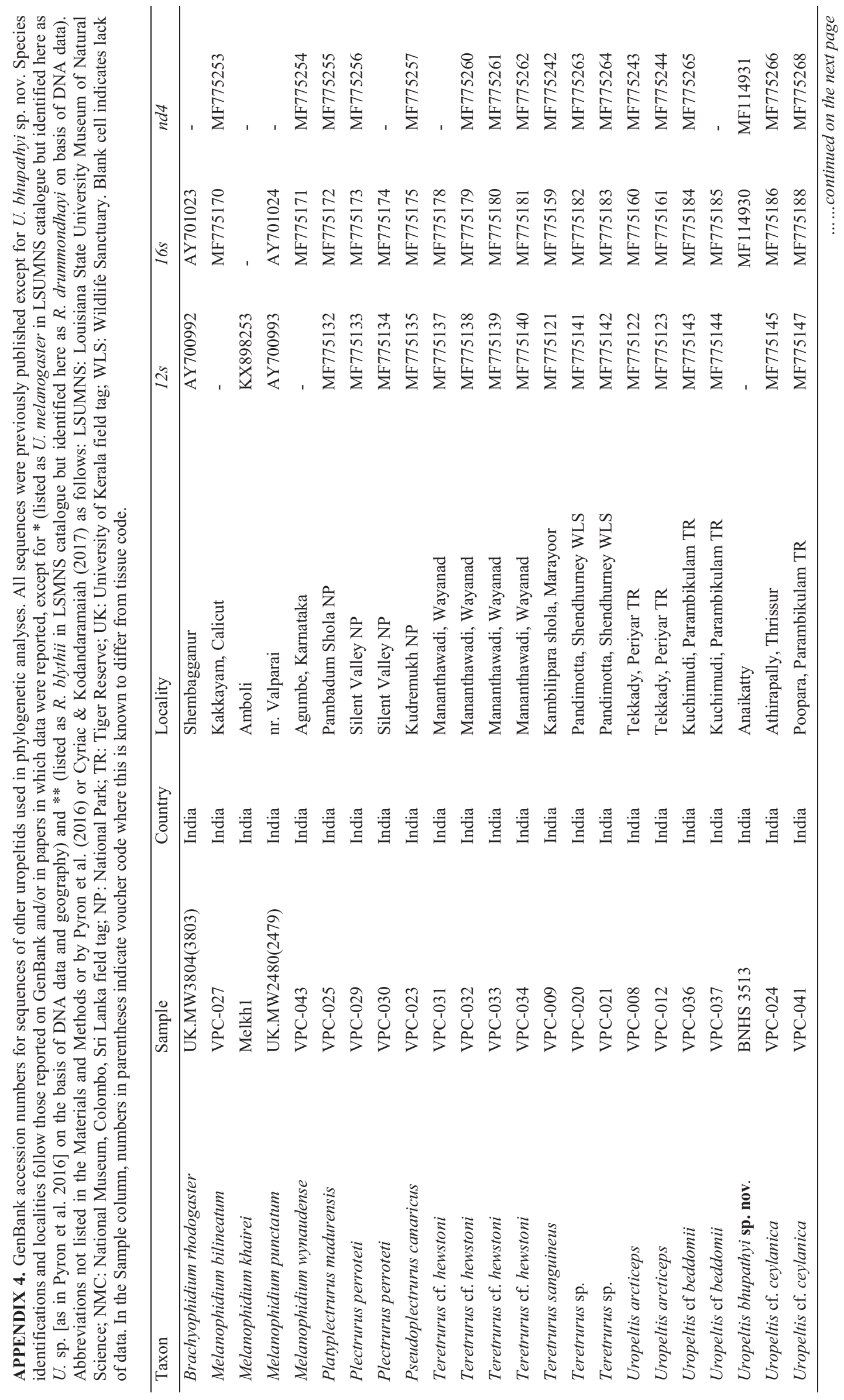




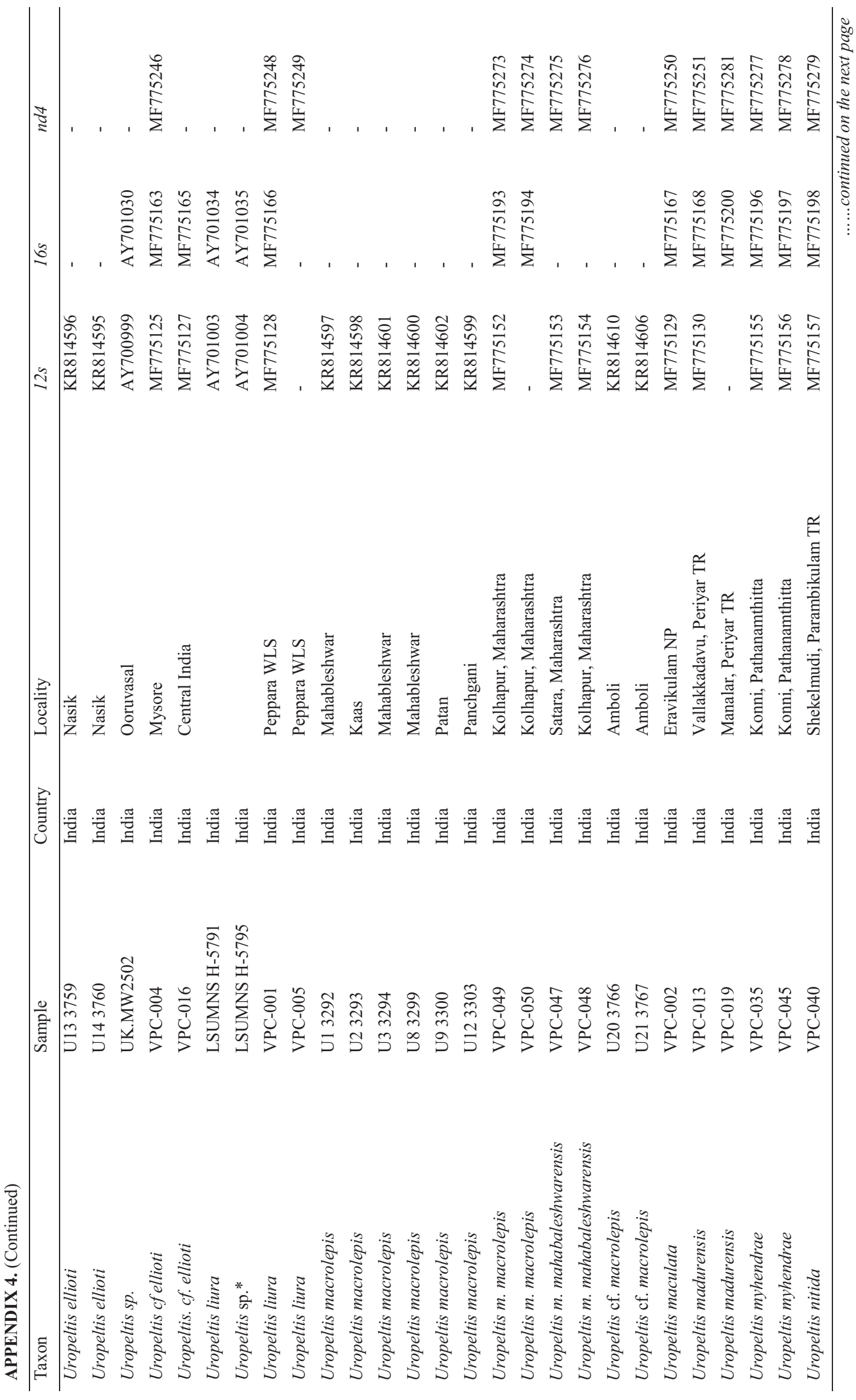




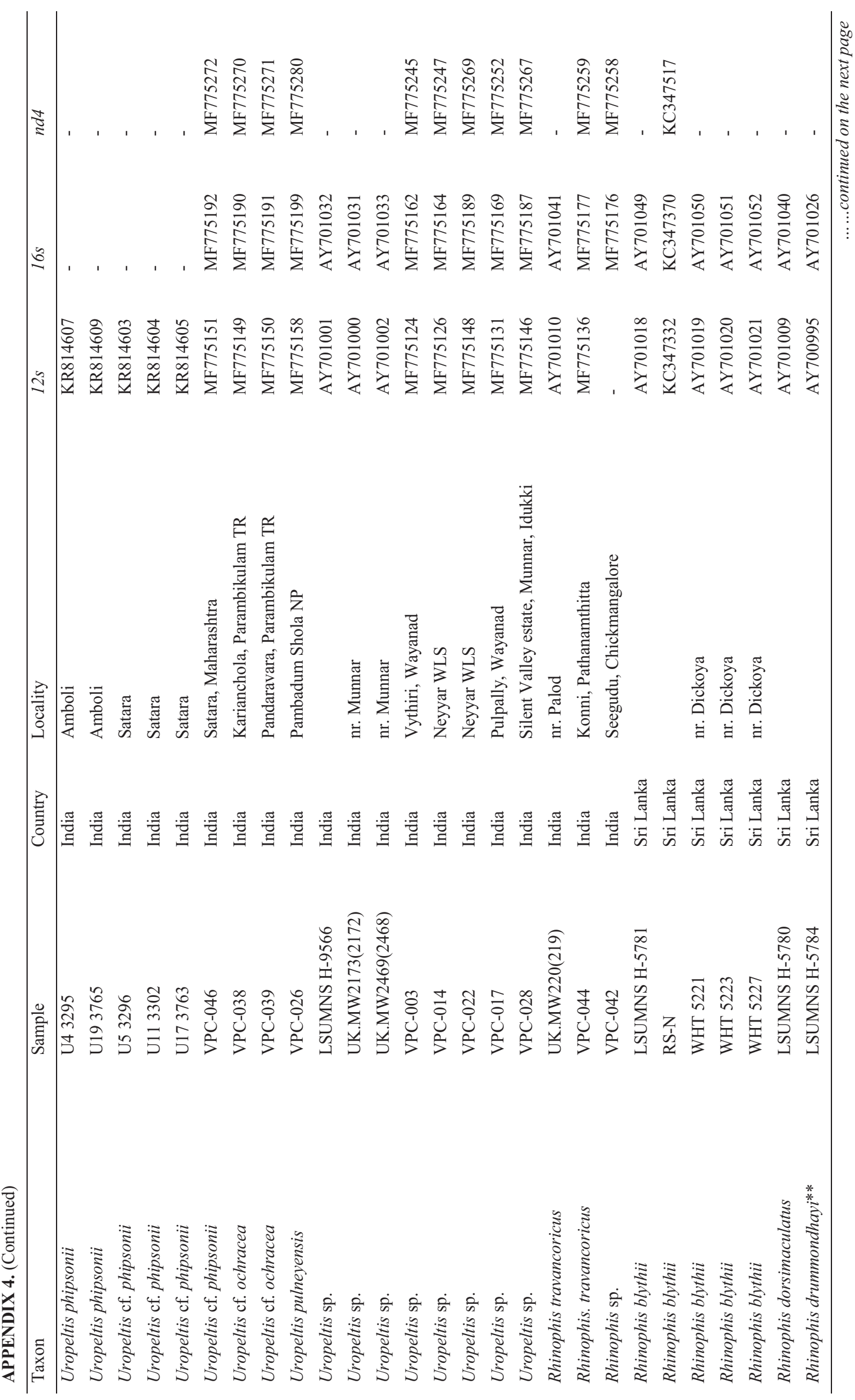




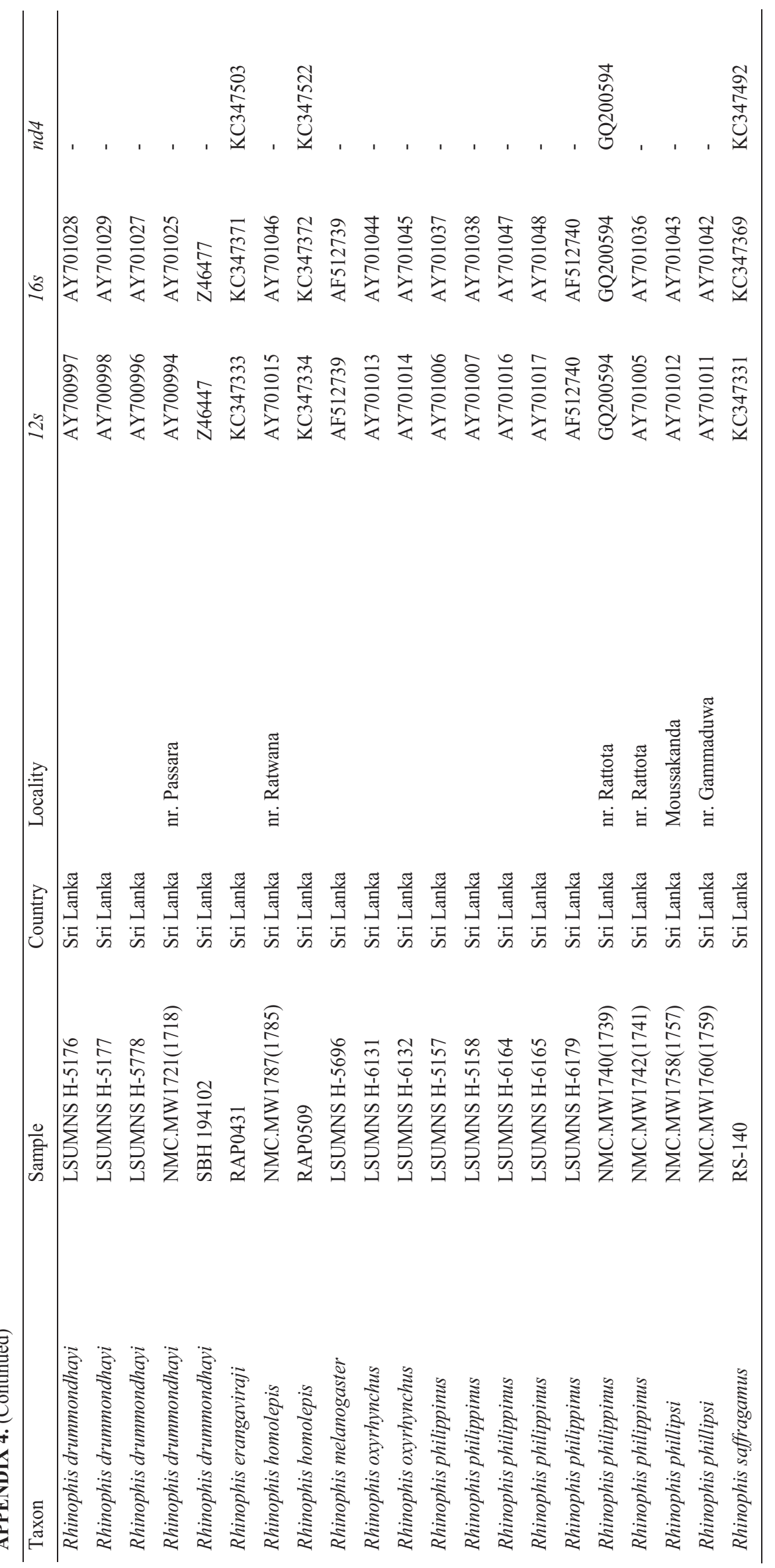

